\title{
Life cycle greenhouse gas emissions from integrated organic farming: a systems approach considering rotation cycles \\ DOI:
}

10.1016/j.spc.2017.12.003

\section{Document Version}

Accepted author manuscript

Link to publication record in Manchester Research Explorer

Citation for published version (APA):

Jeswani, H., Espinoza-Orias, N., Croker, T., \& Azapagic, A. (2018). Life cycle greenhouse gas emissions from integrated organic farming: a systems approach considering rotation cycles. Sustainable Production and Consumption. https://doi.org/10.1016/j.spc.2017.12.003

\section{Published in:}

Sustainable Production and Consumption

\section{Citing this paper}

Please note that where the full-text provided on Manchester Research Explorer is the Author Accepted Manuscript or Proof version this may differ from the final Published version. If citing, it is advised that you check and use the publisher's definitive version.

\section{General rights}

Copyright and moral rights for the publications made accessible in the Research Explorer are retained by the authors and/or other copyright owners and it is a condition of accessing publications that users recognise and abide by the legal requirements associated with these rights.

\section{Takedown policy}

If you believe that this document breaches copyright please refer to the University of Manchester's Takedown Procedures [http://man.ac.uk/04Y6Bo] or contact uml.scholarlycommunications@manchester.ac.uk providing relevant details, so we can investigate your claim.

\section{OPEN ACCESS}




\title{
Life cycle greenhouse gas emissions from integrated organic farming: a systems approach considering rotation cycles
}

\author{
Harish K. Jeswani ${ }^{1}$, Namy Espinoza-Orias ${ }^{1}$, Tim $_{\text {Croker }}{ }^{2}$ and Adisa Azapagic ${ }^{1 *}$ \\ ${ }^{1}$ Sustainable Industrial Systems, School of Chemical Engineering and Analytical Science, The University \\ of Manchester, Manchester M13 9PL, UK \\ 22 Rembrandt Road, London SE13 5QH, UK \\ *Corresponding author: adisa.azapagic@manchester.ac.uk
}

\begin{abstract}
Integrated organic farming could help reduce greenhouse gas (GHG) emissions and other environmental impacts from agriculture but studies of such practices are scarce, particularly those considering farms as whole systems and taking into account rotation cycles. To address this knowledge gap, this study considers life cycle GHG emissions and the related global warming potential (GWP) of a large integrated organic farm in the UK. The farm produces arable crops (wheat, oats, barley, beans and rye), silage and straw, livestock (dairy and beef cows, sheep/lambs and pigs) and related meat products as well as milk and wool. To ensure that the variations in the emissions with crop rotation are taken into account, the study covers a seven-year rotation cycle. The results suggest that the annual GWP of the whole farming system varies from 1816 to $2372 \mathrm{t} \mathrm{CO}_{2} \mathrm{e}$ over the rotation period, averaging $2118 \mathrm{t} \mathrm{CO}_{2} \mathrm{e} / \mathrm{yr}$ or $2.65 \mathrm{t}$ $\mathrm{CO}_{2} \mathrm{e} / \mathrm{ha}$. Dairy and beef cattle are the main contributors, causing $45 \%$ and $39 \%$ of GWP, respectively; this is mainly due to emissions of methane from enteric fermentation and nitrous oxide from manure. Crop cultivation adds a further $10 \%$ to the impact, while the contribution of sheep and pig husbandry is relatively small $(6 \%$ and $<1 \%$, respectively). Per kilogram of meat, lamb and beef have the highest impact, estimated at 12-17.8 and 15.8-18.9 $\mathrm{kg} \mathrm{CO}_{2} \mathrm{e}$, respectively. By comparison, GWP from pig meat ranges from 5.6 to $8.5 \mathrm{~kg} \mathrm{CO} 2 \mathrm{e} / \mathrm{kg}$, largely caused by feed concentrate. The impact from milk production is estimated at $1.02-1.21 \mathrm{~kg} \mathrm{CO} 2 \mathrm{e} / \mathrm{l}$, mostly related to methane emissions from enteric fermentation. The GWP from wool ranges from $20.8-30.9 \mathrm{~kg} \mathrm{CO} \mathrm{CO}_{2} \mathrm{e} / \mathrm{kg}$. Among the crops, beans have the highest average impact $\left(692 \mathrm{~g} \mathrm{CO}_{2} \mathrm{e} / \mathrm{kg}\right)$ and rye the lowest $\left(157 \mathrm{~g} \mathrm{CO}_{2} \mathrm{e} / \mathrm{kg}\right)$. The hotspots for the crops are emissions of nitrous oxide from manure application to land and use of diesel in farm machinery. A sensitivity analysis shows that the assumptions for allocating $\mathrm{N}_{2} \mathrm{O}$ emissions over the rotation cycle have a significant effect on the results. Options for reducing GHG emissions include intercropping, optimisation of feed composition and anaerobic digestion of waste.
\end{abstract}

Keywords: global warming potential; greenhouse gas emissions; integrated organic farming; life cycle assessment; organic produce

\section{Introduction}

With 6.1 billion tonnes of $\mathrm{CO}_{2} \mathrm{e}$ emitted in 2011, agriculture contributes $18 \%$ to global greenhouse gas (GHG) emissions (FAOSTAT, 2015; Olivier et al., 2012). In the UK, it is the second largest source of GHG emissions, after the energy sector, contributing around 9\% to total annual emissions (Webb et al., 2014). Although global emissions from agriculture have increased by $17 \%$ between 1990 and 2011 (FAOSTAT, 2015), in the UK they have shown an opposite trend, decreasing by $20 \%$ over the period. This is due mostly to the decreasing livestock numbers and use of fertilisers (Webb et al., 2014). GHG emissions from agriculture arise mainly from three gases: nitrous oxide $\left(\mathrm{N}_{2} \mathrm{O}\right)$, methane $\left(\mathrm{CH}_{4}\right)$ and carbon dioxide $\left(\mathrm{CO}_{2}\right) \cdot \mathrm{N}_{2} \mathrm{O}$ emissions are mainly caused by application of fertilisers and manure (both applied and excreted on pasture) to soils, which contribute $12 \%$ and $26 \%$ to the global GHG emissions from agriculture, respectively (see Figure 1). The main sources of $\mathrm{CH}_{4}$ emissions are enteric fermentation of dairy, beef and sheep herds (40\%) and manure (26\%). $\mathrm{CO}_{2}$ emissions are also attributable to manure management and to combustion of fuel used for farming activities.

Key recommendations made by expert groups to reduce GHG emissions from agriculture include crop rotations, nutrient recovery and recycling through manure management, improving livestock productivity, pasture and fodder improvements as well as maintenance of soil fertility (Niggli et al., 2009; Gerber et al., 2013). These practices are typically used in organic agricultural systems. However, yields of organic 
crops are generally lower than those of conventional produce due to challenges in maintaining nutrient availability in organic systems (Ponti, et al., 2012).

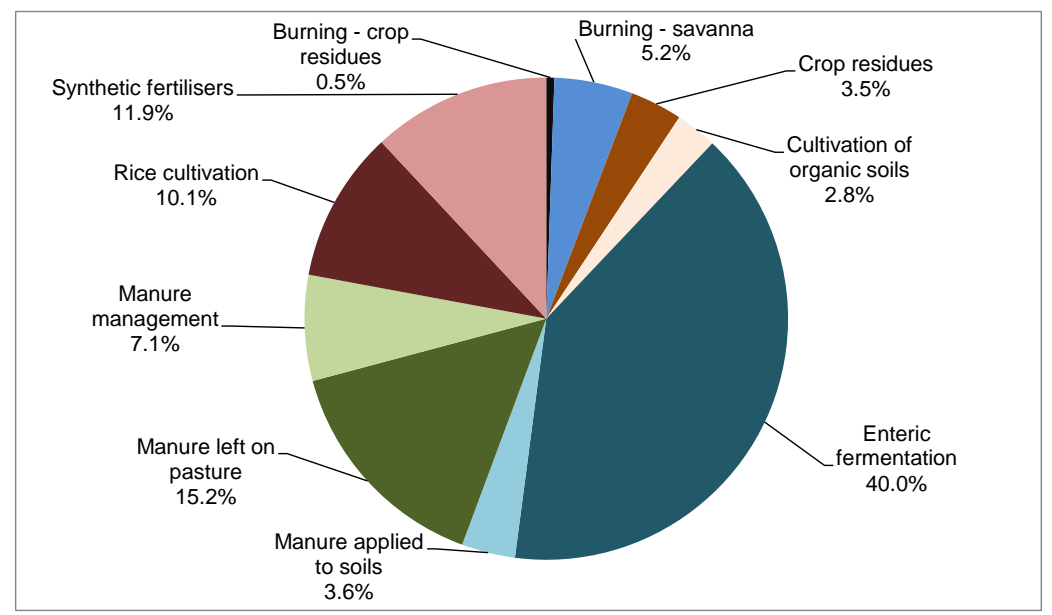

Figure 1 Average contribution of different agricultural activities to global greenhouse gas
emissions from agriculture in the period 1990-2011 (FAOSTAT, 2015)

Organic agriculture is defined by the International Federation of Organic Agriculture Movements (IFOAM, 2008) as a "production system that sustains the health of soils, ecosystems and people". This definition also emphasises its reliance on ecological processes, biodiversity and natural cycles. Four key principles guide organic agricultural practices: health, ecology, fairness and care. Integration of arable crops and animal husbandry into organic farming systems, also referred to as "integrated organic farming" (Panda, 2013), can provide a number of benefits: it fosters internal recycling of nutrients; external inputs are reduced; and it can build self-sufficiency of the farm by reducing purchases of animal feed and concentrates (Peyrauda et al., 2014). It has also been suggested that integrated organic farming systems could help reduce GHG emissions from agriculture (Niggli et al., 2008).

However, studies considering GHG emissions from integrated organic systems are scarce, with most focusing on a single organic produce rather than a farm as an integrated system (for a review see e.g. Roy et al., 2009 and Meier et al., 2015). An exception is a life cycle assessment (LCA) study by Cooper et al. (2011), which considered an eight-year crop rotation cycle to estimate GHG emissions from an integrated organic system producing crops and livestock. However, the emissions were expressed per hectare rather than at the systems or product level. Marton et al. (2016) also assessed GHG emissions of an organic crop-livestock system, but without considering crop rotation and expressing the emissions only at the farm level. Other LCA studies compared GHG emissions of conventional and organic farming in Europe (for a review, see Tuomisto et al., 2012a), showing that organic farming practices generally have lower impacts on the environment per unit of area compared to conventional farming, but not necessarily per unit of product, because of generally lower yields. Specifically, organic beef, olives and some other crops had lower GHG emissions while those from organic milk, cereals and pork were higher compared to conventional products (Tuomisto et al., 2012a).

As observed by Nemecek et al. (2011), most LCA studies have investigated only the average differences between the farming systems, despite a large variation in environmental impacts within each farm. One reason for the variation in the impacts, particularly from integrated farming systems, is the rotation cycle. This aspect has so far received little attention in the literature so that there is scant information on how different rotation cycles and their duration affect the environmental impacts from farming. Tidaker et al. (2014) also note this in their more recent study, recommending that crop sequences rather than single crops be considered when evaluating the impacts of farming systems. 
In a given rotation cycle, the previous crop affects the crop that follows because the crop sequence has an effect on the nutrients' turn-over and soil organic and mineral status. For example, crop residues remaining on the field or the introduction of green manure crops or catch crops in the crop rotation can have a major impact on the subsequent crop and on the crop rotation as a whole by affecting the soil properties and fertility and, consequently, the achievable yield (Nemecek et al., 2015; Brankatschk and Finkbeiner, 2015; Peter et al., 2017). These aspects are particular important in organic agricultural systems which rely to a high degree on recycling of nutrients and using crop residues or green manure crops as a means to fertilise the crops and maintain soil fertility. This constitutes a challenge when using LCA for analysing GHG emissions associated with organic crops, since the crops and their respective yields in an organic crop rotation system are often interlinked through fertility-building (e.g. legumes and beans) and fertility-exploiting crops (e.g. wheat and barley) (Knudsen et al., 2014). Neglecting nutrient shifts from one crop to the subsequent crop leads to free-rider situations for crops that consume nutrients left by the preceding crops (Brankatschk and Finkbeiner, 2015). LCA studies assessing only one crop have a limited ability to include these effects, thus under- or over-estimating the impacts (Tidaker et al., 2014).

In current LCA of agricultural products, most crop-rotation effects are not properly addressed due to methodological challenges (Brankatschk and Finkbeiner, 2015). A number of approaches have been suggested to include crop rotation effects in LCA but so far there is no agreement on how to include the effects of crop rotation in assessing the environmental impacts of a particular crop. Audsley et al. (1997) and Van Zeijts et al. (1999) proposed allocating the burden associated with the application of organic matter according to the land-use share of each crop in the rotation. Knudsen et al. (2014) suggested dividing the environmental burdens and benefits from the catch crops and green manure equally among all crops in the crop rotation cycle over a given area. Use of nitrogen $(\mathrm{N})$ mineralisation rates and $\mathrm{N}$ uptake have been suggested for allocating the environmental burdens of manure, catch crops (Knudsen et al., 2012, Tuomisto et al., 2012b) and compost (Martínez-Blanco et al., 2014). In some studies, the burdens of crop residues are allocated to the subsequent crop (Styles et al., 2015) or a by giving a credit for the nutrients to the current crop if a reduced fertiliser dose is recommended for the subsequent crop (Nemecek et al., 2011). Brankatschk and Finkbeiner (2015) recommend using outputbased allocation approach to model crop-rotation effects in LCA. The authors suggest using the cerealunit allocation approach, which is a bio-physical allocation method based on the nutritional value of agricultural products to animals (Brankatschk and Finkbeiner, 2014).

In an attempt to address some of the gaps discussed above and improve knowledge about integrated organic farming and its impact on climate change, this paper considers a fully integrated organic farming system based in the UK. The aim of the study is to estimate life cycle GHG emissions associated with the production of arable crops, livestock and related products. LCA has been used as a tool for this purpose. To ensure that the variations in the emissions with crop rotation over time are taken into account, a seven-year rotation cycle is considered and the results are estimated at both the systems and product levels. The study also highlights various methodological challenges in conducting LCA of such complex systems.

\section{Methodology}

The study has been carried out following the LCA methodological guidelines in the ISO 14040 and 14044(ISO, 2006a; ISO, 2006b) and PAS 2050 (BSI, 2011) standards. The following sections detail the goal of the study, data and the assumptions.

\subsection{Goal and scope of the study}

The goal of the study is to estimate GHG emissions and the related global warming potential (GWP) associated with agricultural production of arable crops, livestock and their products in an integrated organic farming system. The study also aims to identify the main GWP 'hotspots' and opportunities for improvements, following the key principles of integrated organic farming.

The scope of the study is from 'cradle to farm gate'. The functional unit is defined as 'operation of the farm over a seven-year rotation period'. The activities carried out by the farm and considered in the study are described in the next section. 


\subsection{System definition}

The integrated organic farming system considered in this study is a large integrated organic farm in the UK. An overview of the farm is provided below.

\subsubsection{Overview of the farm}

The farm is located in the South West of England and occupies 800 hectares $\left(8 \mathrm{~km}^{2}\right)$ of land. It has been dedicated to organic agriculture for over 30 years, producing arable crops, silage, straw, livestock, meat, milk and wool. The main arable crops are wheat, oats, barley, beans and rye. The livestock comprises a dairy herd of Ayrshire cows, a beef herd of Aberdeen Angus suckler cows and a sheep flock of Lleyn and Lleyn Cross ewes and rams. The farm also raises rare-breed Tamworth/Large black pigs. The products considered in the study over are given in Table 1.

\section{Table 1 Crops and livestock considered in the study}

\begin{tabular}{ll}
\hline Arable and forage crops & Livestock and related products \\
\hline Winter milling wheat & Sheep, lamb meat and wool \\
Spring oats & Pigs and pig meat \\
Spring beans & Beef cattle and beef meat \\
Spring barley & Dairy cattle, milk and beef meat \\
Rye & \\
Silage & \\
Straw (from all cereals) & \\
\hline
\end{tabular}

The majority of the land is cultivated on a seven-year organic rotation cycle. A typical seven-year rotation cycle consists of three years of clover leys (the main source of nitrogen), followed in year 4 by winter wheat, then by spring oats in year 5, spring beans and barley in year 6 and finally by rye in year 7 . Composted farmyard manure (FYM) from the dairy and beef cattle is spread on fields during the ley years, adding organic matter and nutrients. Catch and cover crops (turnips, brassicas, and mustard) are sown after harvesting to keep the soil covered, reduce soil and nutrient loss and provide forage.

Field operations vary according to the stage in the rotation cycle and the weather/state of the soil. In the first year of leys, a field would typically have the following operations: shallow cultivation and rolling, grass seed planting, manure spreading and then two to three silage cuts. Subsequent years see further manure applications and silage cuts. For the arable phase, the fields are ploughed, pressed, then harrowed and drilled with a combi-planter, harrow-combed (weeded), harvested with a power combine, then weeded again and cover crops planted. Crops are dried using a diesel grain dryer with electric fan.

Following the principles of organic agriculture, the farm aims to minimise inputs and the cattle, when inside, are fed a home-grown forage and straw-based diet. The dairy cattle diet is also supplemented by cereals - from the farm where possible or else purchased in. Artificial pesticides and fertilisers are prohibited. Lime is applied to fields as necessary to balance the soil acidity and trace elements are added if needed. About 120 hectares of permanent pasture are used for grazing, silage production and to increase biodiversity. Hedgerows and field margins are maintained as barriers to pests and a natural habitat to predators.

\subsubsection{System boundaries}

As shown in Figure 2, the following is included within the system boundaries:

- production of farm inputs and transport to the farm (where relevant);

- manufacture and maintenance of farm machinery and milking parlour equipment;

- production of mineral supplements for the livestock and mineral fertilisers;

- cultivation, harvesting, grain drying and storage of harvested crops;

- plastic film for silage bales;

- animal husbandry and slaughter house activities;

- milking parlour operations; and

- on-farm manure management. 
Operation of offices and staff accommodation are excluded from the system boundaries. In accordance with PAS 2050 (BSI, 2011), land use change and soil carbon sequestration are also excluded: the former is not relevant as the land has been used for agriculture for more than 20 years and changes in soil carbon (while they could be significant) are outside the scope of the study.

\subsection{Inventory data}

Primary data have been obtained from the farm. The secondary (background) data have been sourced from IPCC (2006), CCaLC (2013), DEFRA (2014a) and Ecoinvent (2010). The data sources are summarised in Table 2 with further details provided in the subsequent sections.

\subsubsection{Land use}

Three main types of land use are defined: grass leys, arable land and grazing pastures. The rotation sequence for the arable crops over the period of the study was discussed in section 2.2.1. All the cattle graze outdoors for six months (May to October) and are housed for the rest of the year. Sheep and pigs, on the other hand, stay outdoors all year round. Pigs are allocated an exclusive area in the farm, whereas sheep and cattle use the same fields (at different times) for grazing.

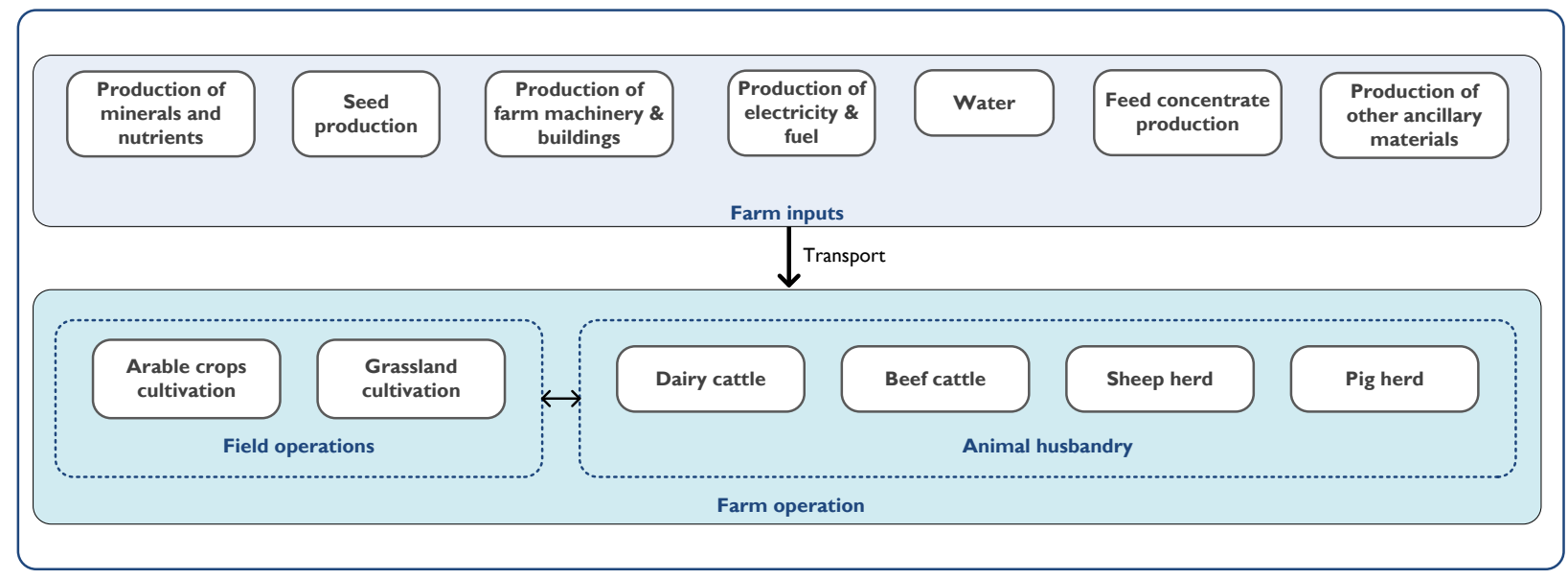

Figure 2 System boundaries for the farm considered in the study

Table 2 Sources of life cycle inventory data

\begin{tabular}{lll}
\hline Data set & Type of data & Source \\
\hline $\begin{array}{l}\text { Farm energy consumption (diesel, electricity) } \\
\text { Inputs for cultivation of arable crops (seeds, manure, lime \& } \\
\text { other nutrients) }\end{array}$ & $\begin{array}{l}\text { Primary } \\
\text { Crop cultivation operations }\end{array}$ & Farm \\
$\begin{array}{l}\text { Livestock (type, number, age groups) } \\
\text { Feed for livestock }\end{array}$ & Primary & Farm \\
& $\begin{array}{l}\text { Primary } \\
\text { Farm outputs (crop yields, livestock, meat, milk, wool) }\end{array}$ & Farm \\
$\begin{array}{l}\text { Emission factors for enteric fermentation, manure } \\
\text { management, fertiliser application, leachate }\end{array}$ & Farm \\
$\begin{array}{l}\text { GHG emissions from energy (diesel, electricity) } \\
\text { GHG emission data for farm machinery production, purchased } \\
\text { seed and feed concentrates, lime production, water supply }\end{array}$ & Primary \\
Road transport & Secondary & IPCC (2006) \\
\hline
\end{tabular}

\subsubsection{Distribution of resources within the farm}

Figure 3 shows the distribution of different resources within the farm. The grassland plots provide grazing animals with fodder, while animals deposit manure (excreta) in return. The FYM deposited during the housing period is collected, composted and applied as organic fertiliser to arable plots as well as 
grassland. This is supplemented by dairy cattle slurry and washings from the milking parlour and barns which are collected throughout the year.

The straw obtained as a co-product of cereal cultivation is mainly used as bedding for the dairy and beef cattle as well as for the pigs, which is subsequently composted with FYM. Silage, produced at the farm from chopped grass cuttings, is fed to the dairy and beef cattle during the in-house periods, supplemented by cereal production saved from a previous harvest. Silage is wilted in the field but not otherwise dried before being baled and wrapped in polyethylene film. The cereal crops are largely produced for sale; however, small amounts are kept for seeds for the following year's crop and are also used to prepare mixed feed concentrate for cows-in-milk.

Pigs are fed exclusively with feed concentrate and minerals bought into the farm. The home-grown diet for sheep and the cattle (dairy and beef) is also supplemented with minor quantities of minerals and feed concentrate.

The milk produced by the dairy cattle is largely sold to a processor for bottling and distribution. The average milk yield of dairy cows is 5965 litres per year per cow. Internal consumption of milk is distributed between calves from the dairy herd (up to $12 \%$ of the volume produced, depending on the number of calves) and the farm personnel (up to $2.5 \%$ ). Calves are fed milk only for a minimum of three months before being introduced to forage and grazing. The male young stock from the dairy cattle herd are transferred to the beef cattle herd after their first year of life.

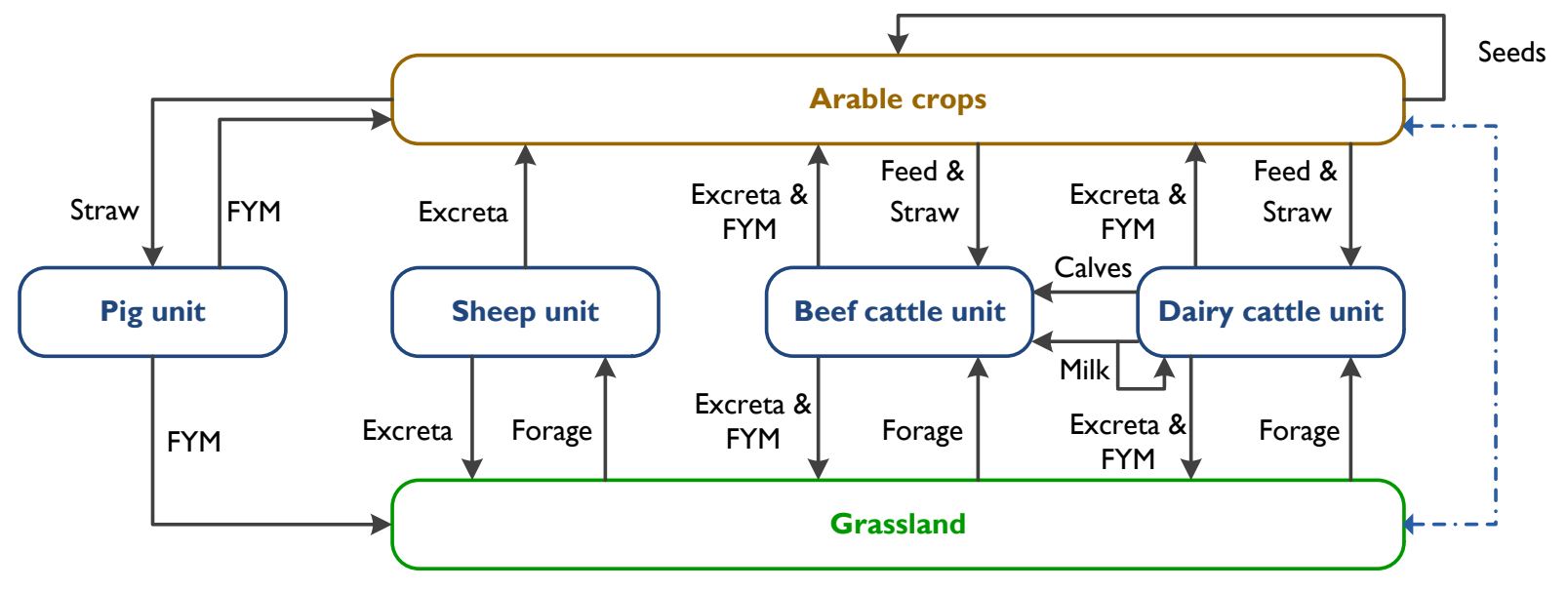

Figure 3 Distribution of resources within the farm

[The dotted lines indicate that grassland is used for arable crops and vice versa in a rotation cycle. Straw is used for bedding for cattle and pigs and cattle feed.]

\subsubsection{Crop cultivation}

\subsubsection{Inputs for crop cultivation}

Crop cultivation involves various field operations and inputs which vary depending on the crop and stage in the rotation cycle; these are detailed in Table 3 . This information has been used to model the annual cultivation activities on each field. However, the sequence of planting the crops within the rotation cycle is not followed strictly in all plots - the study considers the actual rotation cycles for each plot over a sevenyear period.

Sheep and cattle graze in the fields in-between the cropping periods of the rotation cycle. The livestock assist in fertilising the soil by direct deposition of manure and are an integral part of grassland management by reducing excess vegetation and increasing tillering. Mustard, forage rape and stubble turnips are planted as cover crops in-between major crops. The crops are rain-fed, so there is no irrigation. The straw from the cereals (wheat, barley, oats and rye) is baled for storage before being used for bedding and cattle feed. 
Table 3 Standard field operations and inputs over the rotation cycle

\begin{tabular}{|c|c|c|c|c|}
\hline Year & Field operations & $\begin{array}{l}\text { Number } \\
\text { of passes }\end{array}$ & Inputs & $\begin{array}{l}\text { Application } \\
\text { rate }\end{array}$ \\
\hline Year 1: & Terradisk & 2 & & \\
\hline \multirow[t]{7}{*}{ Leys/forage } & Power harrow & 1 & & \\
\hline & Ring-roll & 1 & & \\
\hline & Harrow comb/grass seeder & 1 & Grass seed & $24.7 \mathrm{~kg} / \mathrm{ha}$ \\
\hline & Flat-roll & 1 & & \\
\hline & Fertiliser application & 1 or 2 & Manure/slurry & $12.4 \mathrm{t} / \mathrm{ha}$ \\
\hline & Silage cut & 3 & & \\
\hline & Cattle grazing & & & \\
\hline \multirow{2}{*}{$\begin{array}{l}\text { Year 2: } \\
\text { Leys }\end{array}$} & Fertiliser application & 1 or 2 & Manure/slurry & $12.4 \mathrm{t} / \mathrm{ha}$ \\
\hline & $\begin{array}{l}\text { Sheep grazing } \\
\text { Cattle grazing }\end{array}$ & & & \\
\hline \multirow{2}{*}{$\begin{array}{l}\text { Year 3: } \\
\text { Leys }\end{array}$} & Fertiliser application & 1 or 2 & Manure/slurry & $12.4 \mathrm{t} / \mathrm{ha}$ \\
\hline & $\begin{array}{l}\text { Silage cut } \\
\text { Cattle grazing }\end{array}$ & 1 & & \\
\hline Year 4: & 5 furrow reversible plough & 1 & & \\
\hline Winter & Press with plough & 1 & & \\
\hline \multirow[t]{6}{*}{ milling wheat } & Power harrow/drill combi & 1 & Wheat seeds & $144 \mathrm{~kg} / \mathrm{ha}$ \\
\hline & Harrow comb & $\begin{array}{l}1 \text { if } \\
\text { required }\end{array}$ & & \\
\hline & Combine harvest & 1 & & \\
\hline & Straw baling & 1 & & \\
\hline & Terradisk/seed box & 1 & $\begin{array}{l}\text { Mustard, stubble turnip, } \\
\text { forage rape seeds }\end{array}$ & $7.4 \mathrm{~kg} / \mathrm{ha}$ \\
\hline & Sheep grazing & & & \\
\hline Year 5: & Plough & 1 & & \\
\hline \multirow[t]{6}{*}{ Spring oats } & Press with plough & 1 & & \\
\hline & Power harrow / drill combi & 1 & Oat seeds & $127 \mathrm{~kg} / \mathrm{ha}$ \\
\hline & Harrow comb & $\begin{array}{l}1 \text { if } \\
\text { required }\end{array}$ & & \\
\hline & Combine harvest & 1 & & \\
\hline & Straw baling & 1 & & \\
\hline & Terradisk / seed box & 1 & $\begin{array}{l}\text { Mustard, stubble turnip, } \\
\text { forage rape seeds }\end{array}$ & $7.4 \mathrm{~kg} / \mathrm{ha}$ \\
\hline Year 6: & Plough & 1 & & \\
\hline Beans/ & Press with plough & 1 & & \\
\hline \multirow{5}{*}{$\begin{array}{l}\text { Spring } \\
\text { barley }\end{array}$} & Power harrow/drill combi & 1 & Bean seeds & $254 \mathrm{~kg} / \mathrm{ha}$ \\
\hline & & & Barley seeds & $75 \mathrm{~kg} / \mathrm{ha}$ \\
\hline & Harrow comb & 3 & & \\
\hline & Combine harvest & 1 & & \\
\hline & Straw baling & 1 & & \\
\hline Year 7: & Plough / press & 1 & & \\
\hline \multirow[t]{3}{*}{ Rye } & Combi drill & 1 & Rye seeds & $182 \mathrm{~kg} / \mathrm{ha}$ \\
\hline & Combine harvest & 1 & & \\
\hline & Straw baling & 1 & & \\
\hline
\end{tabular}

In some years in the rotation cycle, a portion of the harvested grains is used as seeds for the next crop as shown in Table 4. Home-grown seeds, however, are not sufficient in most cases and are supplemented with seeds purchased locally, as also indicated in the table.

\subsubsection{Field operations and crop production}

The farm operations that take place over the rotation cycle are summarised in Table S1 in Supplementary Information (SI), together with the total land area covered and the amount of diesel consumed by the farm machinery for different activities. Primary data for diesel consumption have been sourced from the farm and supplemented by data from the literature. However, the values reported in the literature vary significantly, depending on the efficiency of machinery, field topography and soil characteristics. Taking a conservative approach, the highest values for diesel consumption have been assumed in this study. 
However, to reflect the actual annual diesel purchases by the farm, correction factors have been applied to the theoretical diesel consumption values given in Table S1. The correction factors vary for each year, as indicated in Table S2 in SI. In all cases, the actual diesel consumption at the farm was lower than the initial estimates calculated using the values reported in the literature (see Table S1 in SI). The amounts of crops produced over the rotation cycle are summarised in Table 5.

\subsubsection{GHG emissions}

Both direct and indirect $\mathrm{N}_{2} \mathrm{O}$ are considered, including emissions from the application of organic fertilisers, from cover crops and crop residues as well as from nitrate leaching. The main source of $\mathrm{CO}_{2}$ emissions is diesel used in farm machinery; the emission factors for the extraction, refining and combustion of diesel have been taken from DEFRA (2014a). $\mathrm{CO}_{2}$ emissions due to occasional application of lime to correct the soil $\mathrm{pH}$ are also considered and have been calculated using the IPCC Tier 2 characterisation factors (IPCC, 2006).

Table 4 Seed and diesel used over the rotation cycle

\begin{tabular}{|c|c|c|c|c|c|c|c|}
\hline Farm inputs & Year 1 & Year 2 & Year 3 & Year 4 & Year 5 & Year 6 & Year 7 \\
\hline Wheat seeds & 7.6 & 12.35 & 10.4 & 9.8 & 8.7 & 9.5 & 6 \\
\hline$[\mathrm{t} / \mathrm{yr}]^{\mathrm{a}}$ & & $(49 \%)$ & $(100 \%)$ & $(44 \%)$ & $(100 \%)$ & $(21 \%)$ & $(100 \%)$ \\
\hline $\begin{array}{l}\text { Oats seeds } \\
{[\mathrm{t} / \mathrm{yr}]^{\mathrm{a}}}\end{array}$ & 10.93 & 2.52 & 6 & $\begin{array}{l}12.28 \\
(90 \%)\end{array}$ & $\begin{array}{r}8.85 \\
(26 \%)\end{array}$ & 7.5 & 7.5 \\
\hline $\begin{array}{l}\text { Barley seeds } \\
\text { [t/yr] }\end{array}$ & 3 & 2.6 & 2.95 & 3.2 & 5.5 & 3 & 5.15 \\
\hline $\begin{array}{l}\text { Beans seeds } \\
{[\mathrm{t} / \mathrm{yr}]^{\mathrm{a}}}\end{array}$ & 5.65 & 4.9 & 3 & $\begin{array}{r}3.6 \\
(100 \%)\end{array}$ & 7.5 & 3.5 & 1 \\
\hline Rye seeds $[\mathrm{t} / \mathrm{yr}]^{\mathrm{a}}$ & 5 & $\begin{array}{r}7 \\
(14 \%)\end{array}$ & 1.5 & 1.52 & 2 & 2 & $\begin{array}{r}5.5 \\
(100 \%)\end{array}$ \\
\hline $\begin{array}{l}\text { Forage seeds }{ }^{\mathrm{D}} \\
\text { [t/yr] } \\
\text { Diesel }\end{array}$ & 1.26 & 0.85 & 0.95 & 0.63 & 0.52 & 3 & 0.6 \\
\hline consumption [l] & 40,103 & 41,618 & 40,460 & 40,865 & 51,702 & 53,229 & 56,435 \\
\hline
\end{tabular}

Table 5 Annual and total production of arable crops and silage over the rotation cycle [tonnes]

\begin{tabular}{lrrrrrrrr}
\hline Crop & Year 1 & Year 2 & Year 3 & Year 4 & Year 5 & Year 6 & Year 7 & Total \\
\hline Winter wheat grains & 238 & 376 & 464 & 296 & 199 & 216 & 100 & 1889 \\
Spring oat grains & 362 & 221 & 321 & 320 & 339 & 250 & 300 & 2113 \\
Spring barley grains & 38 & 175 & 80 & 103 & 103 & 161 & 123 & 783 \\
Spring beans & 24 & 38 & 9 & 35 & 84 & 17 & 9 & 215 \\
Rye grains & 127 & 112 & 49 & 51 & 83 & 58 & 79 & 559 \\
Straw (all crops) & 727 & 725 & 888 & 725 & 782 & 652 & 538 & 5038 \\
Grass silage & 1406 & 1373 & 1613 & 1723 & 1397 & 1574 & 977 & 10,063 \\
\hline
\end{tabular}

\subsubsection{Sheep and lamb husbandry unit}

A sheep flock of 500 Lleyn and Lleyn Cross ewes and rams is reared at the farm. During the lambing season, the flock size roughly doubles (see Figure S1 in SI). The land occupied for grazing by the sheep and the forage have been allocated on the basis of the number of livestock units, using the allocation factors discussed in section 2.3.10.2. Ewes are fed a supplementary feed concentrate with the ration ranging between 0.01 and $0.04 \mathrm{~kg}$ per head per day. The composition of the feed concentrate has been assumed at $15 \%$ crude protein, $10.5 \%$ crude fibre and $4 \%$ oil (The Organic Feed Company, 2011) and is given in Table S3 in SI. Ewes are also fed mineral supplements, but their contribution to the overall GHG emissions is deemed negligible, assuming a concentration of $50 \mathrm{mg}$ of active compounds per litre of supplement (as per manufacturers' specification). Water required for sheep rearing (Swistock, 2009) and the quantity of nitrogen excreted in sheep manure (DEFRA, 2009a) are detailed in Table 6.

The sheep rearing unit has three main outputs: live sheep, lamb meat and wool. Ewes are shorn once a year, assumed to produce $3 \mathrm{~kg}$ of wool each (Lampkin, 2008). The total weight of live lambs has been 
calculated based on the number of lambs sold plus any change in the stock and the average liveweight per lamb (20 kg); for details, see Table S4 in Supplementary Information. The amount of lamb meat has been estimated using a killing-out percentage (carcass weight as percentage of its liveweight) of $45 \%$ (Williams et al., 2006). The annual and total amounts of different products from this unit are summarised in Table 7.

Table 6 Water consumption and nitrogen excretion by sheep

\begin{tabular}{lcccc}
\hline $\begin{array}{l}\text { Sheep } \\
\text { groups }\end{array}$ & Age & $\begin{array}{c}\text { Weight } \\
{[\mathbf{k g}]}\end{array}$ & $\begin{array}{c}\text { Water } \\
\text { consumption } \\
{[\text { l/day] }}\end{array}$ & $\begin{array}{c}\text { Nitrogen } \\
\text { excreted } \\
\text { [kg N/month] }\end{array}$ \\
\hline Ewes + lambs & $>$ 2 years & 60 & 10 & 0.6 \\
Ewe lambs & 1 to 2 years & 50 & 5 & 0.1 \\
Rams & $>$ 2 years & 80 & 5 & 1.0 \\
Lambs & $<1$ year & $20^{\mathrm{a}}$ & 4 & 0.2 \\
\hline a Average weight of lambs between weaning and finishing & &
\end{tabular}

Table 7 Annual and total products from the sheep, pig and cattle units over the rotation cycle

\begin{tabular}{|c|c|c|c|c|c|c|c|c|}
\hline Product & Year 1 & Year 2 & Year 3 & Year 4 & Year 5 & Year 6 & Year 7 & Total \\
\hline Milk [l] & 718,809 & 773,088 & 812,560 & 824,383 & 792,132 & 748,951 & 766,624 & $5,436,547$ \\
\hline Milk [kg FPCM] ${ }^{\mathrm{a}}$ & 755,233 & 812,262 & 853,734 & 866,156 & 832,271 & 786,902 & 805,471 & $5,712,030$ \\
\hline $\begin{array}{l}\text { Liveweight beef } \\
\text { cattle }[\mathrm{kg}]\end{array}$ & 72,050 & 61,170 & 83,480 & 73,180 & 85,800 & 111,950 & 103,370 & 591,000 \\
\hline Beef meat $[\mathrm{kg}]^{\mathrm{b}}$ & 39,628 & 33,644 & 45,914 & 40,249 & 47,190 & 61,573 & 56,854 & 325,050 \\
\hline $\begin{array}{l}\text { Liveweight pigs } \\
\text { [kg] }\end{array}$ & 2590 & 2010 & 3185 & 2190 & 2620 & 3795 & 1785 & 18,175 \\
\hline Pig meat $[\mathrm{kg}]^{\mathrm{D}}$ & 1865 & 1447 & 2293 & 1577 & 1886 & 2732 & 1285 & 13086 \\
\hline $\begin{array}{l}\text { Liveweight } \\
\text { lambs [kg] }\end{array}$ & 13,080 & 11,320 & 14,380 & 8260 & 9240 & 7560 & 8080 & 71,920 \\
\hline Lamb meat $[\mathrm{kg}]^{\mathrm{b}}$ & 5886 & 5094 & 6471 & 3717 & 4158 & 3402 & 3636 & 32,364 \\
\hline $\begin{array}{l}\text { Liveweight } \\
\text { sheep (excl. } \\
\text { lambs) [kg] }\end{array}$ & 7400 & 4520 & 800 & 7380 & 8420 & 4660 & 12,380 & 45,560 \\
\hline Wool $[\mathrm{kg}]^{\mathrm{c}}$ & 1449 & 1203 & 1083 & 909 & 1146 & 1287 & 1290 & 8367 \\
\hline
\end{tabular}

${ }^{a}$ FPCM: fat and protein corrected milk. Calculated assuming $4.17 \%$ of fat and $3.33 \%$ of protein in the milk (Hanks and Kossaibati, 2013) as follows (AHDB, 2014): $F P C M=M(0.2534+0.1226 \times F+0.0776 \times P)$, where $M$ is the mass of milk [kg], $\mathrm{F}$ the fat and $\mathrm{P}$ the protein content [\%] in milk. Milk density: $1.027 \mathrm{~kg} / \mathrm{l}$.

${ }^{\mathrm{b}}$ Beef meat: $55 \%$ killing-out percentage (KOP); lamb meat: 45\% KOP; pig meat: 72\% KOP (Williams et al., 2006).

${ }^{\mathrm{c}}$ Wool: $3 \mathrm{~kg} / \mathrm{yr}$ obtained from each ewe.

\subsubsection{Pig husbandry unit}

The size of the pigs herd ranges between 30 and 80 heads over the rotation cycle (see Figure S2 in SI). As indicated in Table 8, pigs are classified into five groups: sows, boars, piglets in lactation, weaners and growers. The table also details the amount of water, feed concentrate and bedding required for pig rearing as well as the excretion of nitrogen. These have been calculated on the basis of the number of pigs, age and weight, also shown in the table.

The composition of the concentrate fed to sows, boars and piglets is given in Table S5 in Supplementary Information. Note that organic agricultural practices require that organic livestock should be fed organic feed concentrate (Edwards, 2002). Exceptions are made in the case of unavailability of organic feed, allowing for feed coming from 'in-conversion' holding or non-organic sources. GHG emissions from the organic feed concentrate have been modelled using data from the Ecoinvent (2010) and CCaLC (2013) databases.

The outputs from the pigs rearing unit are assumed to be grower piglets, with a finishing weight of $35 \mathrm{~kg}$. The total weight of live pigs has been calculated based on the number of grower piglets sold plus any change in the stock and their respective liveweight (as detailed in Table S6 in SI). The total amount of pig 
meat produced by the farm has been estimated based on a killing-out percentage of $72 \%$ (Williams et al., 2006). The annual and total amounts of pig meat can be found in Table 7.

\subsubsection{Beef cattle husbandry unit}

A beef herd of 80 to 140 Aberdeen Angus suckler cows and 200 to 300 young stock are reared at the farm. The herd is classified into five groups: cows, bulls, young stock younger than one year, young stock between one and two years old and young stock older than two years. As mentioned before, the herd is housed indoors during the winter months and for the rest of the year it grazes outdoors. Different groups of cattle graze different plots as well as some of the arable land during the fallow period in-between crops. These movements are complex and it was not feasible to allocate each plot to different groups of cattle over the rotation cycle. Instead, the land classified as 'pasture' has been allocated to the herd on the basis of the number of livestock units.

Table 9 details the inputs required for beef cattle rearing and manure they generate (as nitrogen excretion), calculated on the basis of their number, age and weight. The cows-in-milk are fed a concentrate with the composition given in Table S7 in SI.

As for the other livestock, the total weight of beef cattle has been estimated based on the number of animals sold plus any change in the stock and their respective liveweight (Table S8 in SI). The total amount of beef meat produced by the farm has been estimated assuming a killing-out percentage of $55 \%$ (Williams et al., 2006). The annual and total amounts of beef are detailed in Table 7.

Table 8 Inputs into the pig units and manure (nitrogen) excretion

\begin{tabular}{|c|c|c|c|c|c|c|}
\hline $\begin{array}{l}\text { Pig } \\
\text { groups }\end{array}$ & Age & $\begin{array}{l}\text { Weight } \\
{[\mathrm{kg}]}\end{array}$ & $\begin{array}{c}\text { Water } \\
\text { consumption } \\
{[\mathrm{l} / \mathrm{day}]} \\
\text { (Swistock, 2009) }\end{array}$ & $\begin{array}{l}\text { Feed ration } \\
\text { [kg/day] } \\
\text { (Martins et al., } \\
\text { 2002) }\end{array}$ & $\begin{array}{c}\text { Bedding }^{\mathrm{a}} \\
{[\mathrm{kg}} \\
\text { straw/month] }\end{array}$ & $\begin{array}{c}\text { Nitrogen excreted } \\
\text { [kg N/month] } \\
\text { (DEFRA, 2009a; } \\
\text { Martins et al., 2002) }\end{array}$ \\
\hline Sows & $>1$ year & 225 & 15 & 1.7 & 27.2 & 1.33 \\
\hline Boars & $>1$ year & 250 & 15 & 1.7 & 27.2 & 1 \\
\hline $\begin{array}{l}\text { Piglets in } \\
\text { lactation }\end{array}$ & $\begin{array}{l}\text { Up to } 5 \\
\text { weeks }\end{array}$ & 7 & & & 6.8 & \\
\hline Weaners & $6-10$ weeks & $18^{\mathrm{b}}$ & 2 & $0.5-1$ & 13.6 & 0.5 \\
\hline Growers & $11-16$ weeks & $30^{b}$ & 4.5 & $1-2$ & 13.6 & 0.7 \\
\hline
\end{tabular}

Table 9 Inputs into the beef and dairy cattle units and manure (nitrogen) excretion

\begin{tabular}{|c|c|c|c|c|c|}
\hline Cattle type and groups & $\begin{array}{c}\text { Weight } \\
{[\mathrm{kg}]}\end{array}$ & $\begin{array}{c}\text { Water } \\
\text { consumption } \\
{[1 / \text { day }]^{\mathrm{a}}}\end{array}$ & $\begin{array}{c}\text { Feed ration } \\
\text { (dry matter) } \\
\text { [kg/day] }^{\mathrm{b}}\end{array}$ & $\begin{array}{c}\text { Bedding } \\
{[\mathrm{kg}} \\
\text { straw/month] }^{\mathrm{b}, \mathrm{c}} \\
\end{array}$ & $\begin{array}{c}\text { Nitrogen } \\
\text { excreted } \\
{\text { [kg N/month }]^{d}}^{\text {dkg }}\end{array}$ \\
\hline \multicolumn{6}{|l|}{ Beef cattle } \\
\hline Cows & 650 & 55 & 10 & 54 & 5 \\
\hline Bulls & 1000 & 38 & 10 & 54 & 4 \\
\hline Young stock $<1$ year & $180-200$ & 14 & 5 & 27 & 2.8 \\
\hline Young stock 1 to 2 years & 400 & 38 & 6.5 & 54 & 4 \\
\hline Young stock $>2$ years & $540-580$ & $38-45$ & 9 & 54 & 4 \\
\hline \multicolumn{6}{|l|}{ Dairy cattle } \\
\hline Cows-in-milk & 550 & 75 & 10 & 54 & 6.4 \\
\hline Dry cows & 550 & 41 & 10 & 54 & 5 \\
\hline Young stock $<1$ year & $140-180$ & 14 & 5 & 27 & 3 \\
\hline Young stock 1 to 2 years & 400 & 25 & 6.5 & 54 & 5 \\
\hline Young stock $>2$ years & 500 & 25 & 9 & 54 & 5 \\
\hline
\end{tabular}




\subsubsection{Dairy cattle husbandry unit}

A dairy herd of between 150 and 180 Ayrshire cows and 70 to 95 young stock are reared at the farm. The herd is classified into six groups: cows-in-milk, dry cows, barren cows, calves younger than one year, heifers between one and two years old and heifers older than two years (see Table S9 in SI). The farm has a year round calving pattern. However, there are more cows in calving in September to February and less at other times. Like the beef cattle, the dairy herd also stays indoors during the winter and outdoors in the summer. They also graze various land plots so that the land classified as 'pasture' has been allocated to the herd on the basis of the number of livestock units, in the same way as for the beef cattle.

The inventory data are summarised in Table 9. The water and feed consumption have been calculated on the basis of the cattle number, age and weight. In addition to these, the milking parlour requires $30 \mathrm{I}$ of water per cow per day for cleaning and $0.12 \mathrm{kWh}$ of electricity per litre of milk. The cows-in-milk are given the same feed concentrate as the beef cattle (see Table S7 in SI).

The outputs from the dairy cattle unit are milk, dairy stock, spent cows and young stock (one-year old). The male young animals and the surplus female young stock are transferred to the beef cattle unit and accounted for in that unit. The annual and total amounts of the outputs from the dairy unit are listed in Table 7 and Table S9 in the SI.

\subsubsection{Slaughterhouse}

For the slaughterhouse, the slaughtering process, cooling, washing and cleaning operations have been considered. As shown in Table 10, the data for energy, water and wastewater have been obtained from Blonk Agri-footprint BV (2015), while the detergent quantities have been sourced from EC (2005). Slaughterhouse by-products include hide, blood, fat and bones. Given that these by-products are of low value and require further processing in tanneries and rendering plants, all impacts have been allocated to meat.

Table 10 Inventory data for the slaughterhouse

\begin{tabular}{lccccc}
\hline & $\begin{array}{c}\text { Electricity } \\
{[\mathrm{kWh} / \mathrm{kg} \text { liveweight }]}\end{array}$ & $\begin{array}{c}\text { Natural gas } \\
{[\mathrm{MJ} / \mathrm{kg} \text { liveweight }]}\end{array}$ & $\begin{array}{c}\text { Water } \\
{[\mathrm{l} / \mathrm{kg} \text { liveweight }]}\end{array}$ & $\begin{array}{c}\text { Detergent } \\
{[\mathrm{g} / \mathrm{kg} \text { liveweight }]}\end{array}$ & $\begin{array}{c}\text { Wastewater } \\
{[\mathrm{l} / \mathrm{kg} \text { liveweight] }}\end{array}$ \\
\hline $\begin{array}{l}\text { Cattle and } \\
\text { sheep }\end{array}$ & 0.109 & 0.15 & 2 & 0.11 & 2 \\
Pigs & 0.106 & 0.24 & 2.5 & 0.58 & 2.5 \\
\hline
\end{tabular}

\subsubsection{GHG emissions from enteric fermentation and manure}

The estimates of enteric and manure emissions of GHG are based on the age and weight of animals for each type of the herd reared at the farm. They have been calculated using the IPCC Tier 1 factors for sheep and pigs and Tier 2 factors for dairy and beef cattle (IPCC, 2006), in accordance with PAS 2050 (BSI, 2011). The direct and indirect emissions of methane and $\mathrm{N}_{2} \mathrm{O}$ from manure deposition have been calculated for the annual average temperature for the UK's South West region of below $15^{\circ} \mathrm{C}$. The emissions arising from the excreta deposited on the soil while grazing have been allocated entirely to the animals. The emissions arising from dairy and beef cattle manure management (as compost) during the indoors period have been allocated to the animals, whereas the emissions resulting from the application of compost as organic fertiliser have been allocated to the crops. Allocation is discussed in more detail below.

\subsubsection{Allocation}

The farm is a complex integrated system, whereby land and other resources are shared by and transferred between different activities. Furthermore, several units within the system produce co-products. Consequently, allocation of resources and GHG emissions among different farm activities and coproducts is necessary. Following the ISO 14044 standard (ISO, 2006b), the inputs and emissions were first subdivided where possible and then the remainder was allocated on a biophysical basis as recommended in various guidelines (e.g. Audsley et al., 1997; IDF, 2015; FAO, 2016a,b). A number of biophysical approaches have been suggested for agricultural systems, such as nutrient requirements of crops (Martínez-Blanco et al., 2014; FAO, 2016b), nutrient uptake of crops (Tuomisto et al., 2012b), nitrogen mineralisation rate (FAO, 2016b, Martínez-Blanco et al., 2014; Knudsen et al., 2012), 
physiological feed requirements of animals (FAO, 2016a; IDF, 2015), protein content (Wiedemann et al., 2015), metabolisable energy content (Brankatschk and Finkbeiner, 2014), etc. The allocation approaches used in this study are summarised in Table 11 and the rationale behind is discussed in the following sections.

\section{Table 11 Allocation methods considered in the base case}

\begin{tabular}{lll}
\hline Sub-system & Activities and products & Allocation method \\
\hline Crops & Diesel use for crops & Avoided by using crop-specific data \\
& Other inputs (seeds, machinery, etc.) & Avoided by using crop-specific data \\
& $\mathrm{N}_{2} \mathrm{O}$ emissions from fertiliser application (slurry, & In proportion to nitrogen availability for plants \\
& manure, cover crops and crop residue) & (mineralisation rate) over the rotation period \\
& Allocation between grain and cereals & Metabolisable energy content \\
Livestock & Grazing and forage & Livestock unit (feed requirements) \\
& Feed (concentrate and silage) and other inputs & Avoided by using animal-specific data \\
& GHG emissions from excreta and manure & Allocated to the producing animals \\
& management system & Energy requirement \\
& Products from dairy unit (milk and beef) & Protein content \\
\hline
\end{tabular}

2.3.10.1 Allocation of $\mathrm{N}_{2} \mathrm{O}$ emissions from organic fertilisers during the rotation cycle

In a farm following organic agricultural practices, nitrogen fixing by legumes is the primary source of nitrogen fertiliser and the application of manure produced by the farm's livestock serves the purpose of internal nutrient recycling. Nitrogen is present in organic fertilisers in two main forms: organic and inorganic. Inorganic $\mathrm{N}$ is readily available to plants in the forms in which it commonly occurs (mostly ammonium and nitrate), while organic $\mathrm{N}$ is mineralised slowly over a period of months to years, through the action of soil microbes, to become potentially available for crop uptake (DEFRA, 2010). Therefore, the allocation of $\mathrm{N}_{2} \mathrm{O}$ emissions from cattle slurry and FYM has been carried out based on the nitrogen availability to plants (based on mineralisation rate) over the seven-year rotation cycle. The basis for the allocation for each crop is as follows: firstly plant available nitrogen (PAN) in each year is estimated using data for composition of organic and inorganic nitrogen in slurry and FYM (DEFRA, 2010) and annual mineralisation rates for organic nitrogen over the rotation period (Sullivan, 2008). The allocation factors for each year have been calculated by dividing PAN in each year with total PAN over the seven-year rotation period as detailed in Table 12. Each application of organic fertiliser in a given plot of land is considered as the start of the allocation cycle. However, considering that crop in years 1-6 would benefit from the fertiliser applied in the previous rotation, while the fertiliser applied in years 2-7 would benefit the crops in the next rotation, these effects have been accounted within this rotation assuming similar application of organic fertilisers in the previous rotation. Therefore, in any given year, the total $\mathrm{N}_{2} \mathrm{O}$ emissions associated with a given plot of land represent the sum of the emissions allocated over the seven years. Since most of the PAN from crop residue and cover crops is released in the first year (Sullivan and Andrews, 2012; Lynch et al., 2016), all $\mathrm{N}_{2} \mathrm{O}$ emissions from crop residues and cover crops have been allocated to the next crop. Alternative methods to allocate $\mathrm{N}_{2} \mathrm{O}$ emissions are considered in the sensitivity analysis (see section 3.7).

Table 12 Allocation factors for nitrogen application during the rotation cycle ${ }^{a}$

\begin{tabular}{|c|c|c|c|c|c|c|c|}
\hline \multirow[t]{2}{*}{ Nitrogen source } & \multicolumn{7}{|c|}{ Allocation factor [\%] } \\
\hline & Year 1 & Year 2 & Year 3 & Year 4 & Year 5 & Year 6 & Year 7 \\
\hline Slurry after volatilisation & 80 & 10 & 5 & 2 & 1 & 1 & 1 \\
\hline FYM after volatilisation & 53 & 12 & 12 & 7 & 5 & 5 & 5 \\
\hline Cover crops and crop residue & 100 & 0 & 0 & 0 & 0 & 0 & 0 \\
\hline
\end{tabular}

Before the allocation is applied, it is necessary to consider the losses of nitrogen as ammonia (by volatilisation) which in turn vary depending on the manure management system. For slurry and FYM from dairy cattle, the loss factor is $40 \%$ (IPCC, 2006). The total amount of nitrogen (N) applied to a given plot of land has been calculated as follows: 
$\mathrm{N}$ applied $=\mathrm{N}$ contained in residues of main crops and cover crops $+\mathrm{N}$ in slurry after volatilisation $+\mathrm{N}$ in FYM after volatilisation

where:

$\mathrm{N}$ contained in residues of main crops and cover crops is calculated for each crop according to IPCC (2006)

$\mathrm{N}$ in slurry after volatilisation $=0.6 \times 2[\mathrm{~kg} \mathrm{~N} / \mathrm{t}$ slurry $]=1.2[\mathrm{~kg} \mathrm{~N} / \mathrm{t}$ slurry] (DEFRA, 2009a)

$\mathrm{N}$ in FYM after volatilisation: 0.6 x 5.9 [kg N/t FYM] = 3.5 [kg N/t FYM] (DEFRA, 2009a).

\subsubsection{Allocation of grazing land and forage to livestock}

Table 13 details how the farm management allocates the forage cultivated at the farm to the livestock on the basis of total livestock units. The allocation criteria based on livestock units have been used to allocate the GHG emissions from forage cultivation to the cattle and sheep. As mentioned earlier, pigs are fed exclusively with feed concentrate and hence allocation is not applicable.

Table 13 Allocation of grazing and forage land to livestock based on farm records

\begin{tabular}{|c|c|c|c|}
\hline Livestock & Group & $\begin{array}{c}\text { Livestock } \\
\text { unit factor }^{\mathrm{a}}\end{array}$ & $\begin{array}{l}\text { Allocation } \\
\text { factor [\%] }\end{array}$ \\
\hline \multirow[t]{3}{*}{ Sheep } & Lowland ewes & 0.17 & 12.7 \\
\hline & Other sheep (rams, stores) & 0.1 & 0.6 \\
\hline & Ewe lambs & 0.1 & 0.4 \\
\hline Dairy cattle & Dairy cows & 1 & 31.5 \\
\hline \multirow[t]{3}{*}{ Dairy young stock } & $>2$ years & 0.8 & 2.9 \\
\hline & 1 to 2 years & 0.6 & 3.8 \\
\hline & $<1$ year & 0.4 & 2.5 \\
\hline Dairy bred beef & $<1$ year & 0.4 & 6.1 \\
\hline \multirow[t]{5}{*}{ Beef cattle } & Cows & 0.6 & 10.6 \\
\hline & Bulls & 0.6 & 0.5 \\
\hline & $>2$ years & 0.8 & 3.1 \\
\hline & 1 to 2 years & 0.6 & 14.9 \\
\hline & $<1$ year & 0.4 & 7.9 \\
\hline
\end{tabular}

Table 14 Biophysical allocation factors for products and co-products [\%]

\begin{tabular}{llrrrrrrr}
\hline Sub-system & $\begin{array}{l}\text { Products and } \\
\text { co-product }\end{array}$ & Year 1 & Year 2 & Year 3 & Year 4 & Year 5 & Year 6 & Year 7 \\
& Wheat grains & 66 & 67 & 68 & 66 & 62 & 66 & 66 \\
Wheat & Wheat straw & 34 & 33 & 32 & 34 & 38 & 34 & 34 \\
Oat & Oat grains & 76 & 82 & 75 & 76 & 72 & 76 & 76 \\
& Oat straw & 24 & 18 & 25 & 24 & 28 & 24 & 24 \\
Barley & Barley grains & 70 & 81 & 68 & 70 & 62 & 70 & 70 \\
& Barley straw & 30 & 19 & 32 & 30 & 38 & 30 & 30 \\
Rye & Rye grains & 61 & 68 & 53 & 61 & 64 & 61 & 61 \\
\multirow{5}{*}{ Dairy } & Rye straw & 39 & 32 & 47 & 39 & 36 & 39 & 39 \\
& Milk & 92 & 89 & 87 & 88 & 82 & 88 & 80 \\
Sheep & Meat \& stock & 8 & 11 & 13 & 12 & 18 & 12 & 20 \\
& Lamb & 50 & 55 & 74 & 43 & 42 & 44 & 32 \\
& Sheep & 28 & 22 & 4 & 39 & 38 & 27 & 49 \\
& Wool & 22 & 23 & 22 & 18 & 20 & 29 \\
\hline
\end{tabular}

2.3.10.3 Allocation of GHG emissions between co-products

Allocation of GHG emissions between the co-products obtained from the various units at the farm (cereals and straw; milk, dairy young stock and dairy stock culls; lamb meat, sheep stock and wool) has been carried out on a biophysical basis. Other allocation approaches based on mass and economic are considered as part of the sensitivity analysis. Table 14 specifies the biophysical allocation factors for the cereals and straw applied in each year over the rotation cycle, based on the metabolisable energy of 
cereals and straw as suggested by Brankatschk and Finkbeiner (2014). The metabolisable energy of cereals and straw have been obtained from AHDB (2017).

The outputs of the dairy unit are milk, dairy stock culls, beef and the male young stock transferred to the beef cattle unit. The GHG emissions have been allocated using the biophysical approach as recommended by FAO (2016) and IDF (2015). This approach reflects the causal relationship between the energy content in the feed and the physiological requirements to produce milk and beef. The following equation from IDF (2015) has been used to calculate the allocation factor for milk and meat:

Allocation factor for milk $=1-6.04 \times$ BMR

where BMR is the ratio of liveweight of stock sold or transferred annually to the beef unit to the mass of fat and protein corrected milk (FPCM) produced per year.

Allocation of GHG emissions from the sheep unit is more complex as wool production is mainly determined by requirements for protein, rather than energy, which in turn is a key determinant for milk production. Here, co-production of wool and liveweight (for meat) has been modelled following Wiedemann et al. (2015) using the protein mass allocation (PMA) method. The protein content in sheep and lamb liveweight has been assumed at $18 \%$ and in greasy wool at $70 \%$ (Wiedemann et al., 2015). Allocation is not necessary for beef cattle as beef is the only product from this unit.

Furthermore, all the GHG emissions from the generation and management of manure have been allocated to the management of beef and dairy cattle. This means that manure, used as fertiliser, has a zero GHG emissions for crops; however, the emissions from its application to land are allocated to the crops as detailed in section 2.3.8.

\section{Results and discussion}

Global warming potential estimated for the whole farm over the rotation period is summarised in Figure 4. As indicated in the figure, the annual impact varies from 1816 to $2372 \mathrm{t} \mathrm{CO}_{2} \mathrm{e}$, with an average value of $2118 \mathrm{t} \mathrm{CO}_{2} \mathrm{e} / \mathrm{yr}$. Dairy and beef cattle units are the main contributors, causing $45 \%$ and $39 \%$ of the impact, respectively. This is mainly due to $\mathrm{CH}_{4}$ emissions from enteric fermentation and $\mathrm{N}_{2} \mathrm{O}$ emissions from the excreta deposition. Crop cultivation is the third most significant contributor with $10 \%$, while the contributions of sheep and pigs are relatively small ( $6 \%$ and $<1 \%$, respectively). The GWP of different farm activities and products is discussed in the following sections.

\subsection{Crop cultivation}

GWP arising from the cultivation of crops over the rotation period is shown in Figure 5; further details can be found in Tables S10 in SI. The results in Figure 5 suggest that rye has the lowest average GWP over the rotation cycle $\left(157 \mathrm{~g} \mathrm{CO}_{2} \mathrm{e} / \mathrm{kg}\right)$ and beans the highest $\left(692 \mathrm{~g} \mathrm{CO}_{2} \mathrm{e} / \mathrm{kg}\right)$. The impact from barley and oats is similar, estimated at 350 and $369 \mathrm{~g} \mathrm{CO}_{2} \mathrm{e} / \mathrm{kg}$, respectively, followed by wheat at $232 \mathrm{~g} \mathrm{CO}_{2} \mathrm{e} / \mathrm{kg}$. Silage emits $166 \mathrm{~g} \mathrm{CO}_{2} \mathrm{e} / \mathrm{kg}$ and straw $128 \mathrm{~g} \mathrm{CO}_{2} \mathrm{e} / \mathrm{kg}$.

As can also be seen in Figure 5, there is a wide annual variation in the impact for each crop. For example, the GWP of wheat ranges from $183 \mathrm{~g} \mathrm{CO}_{2} \mathrm{e} / \mathrm{kg}$ in year 2 to $392 \mathrm{~g} \mathrm{CO}_{2} \mathrm{e} / \mathrm{kg}$ in year 7 . The variation is even greater for beans: from $525 \mathrm{~g} \mathrm{CO}_{2} \mathrm{e} / \mathrm{kg}$ in year 4 to $1567 \mathrm{~g} \mathrm{CO}_{2} \mathrm{e} / \mathrm{kg}$ in year 6 . There are several reasons for these variations, including different amounts of crops planted, the size of the plots used and the related annual production (see Table 5). Furthermore, the yield of beans varied widely, from 0.7 to $2.5 \mathrm{t} / \mathrm{ha}$ during the seven-year period. It is also possible that in some seasons the crop was partly ploughed in or not fully harvested. Moreover, compared to the cereals, beans were cultivated on the smallest area throughout the rotation (see Table S11 in SI). Finally, the sequence of planting the crops within the rotation cycle is not necessarily followed in all plots and, in some cases, the same crop was grown for two or three consecutive years in the same plot. Therefore, these results illustrate the importance of considering full rotation cycles for more accurate estimations of GHG emissions of crops (and other agricultural products, as discussed further below). 


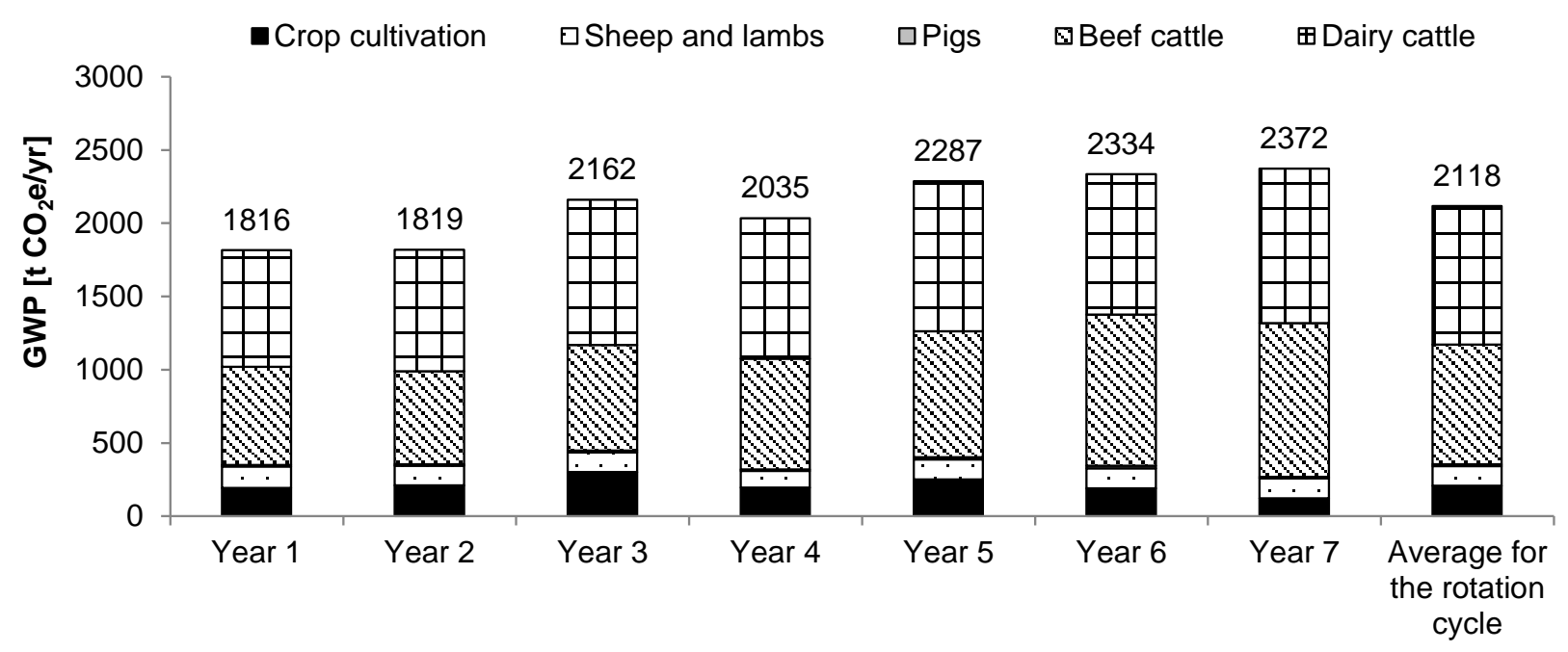

Figure 4 Global warming potential (GWP) for the whole farm over the rotation period

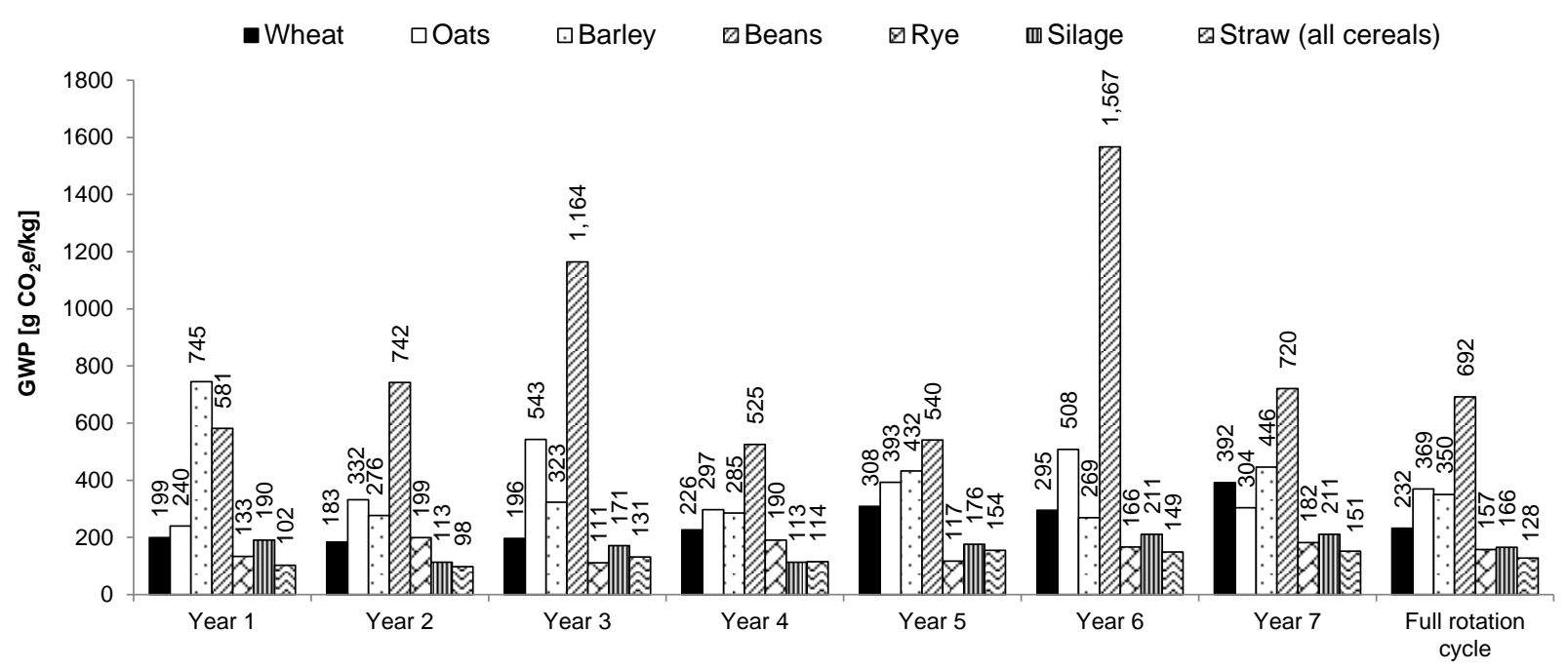

Figure 5 Global warming potential (GWP) of arable crops and co-products over the rotation cycle [GWP for each product obtained by dividing the GWP values in Table S10 by the total amount of crops produced annually and over the full rotation period (Table 5), respectively. GWP for straw represents the average for all cereals.]

The contribution analysis in Figure 6 and Figure S3 in SI indicates that the largest contributors to GWP of crops are $\mathrm{N}_{2} \mathrm{O}$ emissions from manure application to the land and the arable operations (diesel used in the farm machinery and grain drying). As mentioned earlier, no GHG emissions are associated with the production of manure because they have been allocated to the rearing of livestock. The contribution of liming and the related $\mathrm{CO}_{2}$ emissions is also relevant for some crops, in particular for oats and silage, but only in some years as liming is not carried out on an annual basis (see Figure S3). In the case of beans, the contribution of seeds to GHG emissions is significant. This is due to the higher GHG emission factor for bean seeds and a relatively higher amount of seeds used per hectare compared to other crops. For grains, the contribution of machinery varies from $8 \%$ (oat) to $15 \%$ (wheat). 


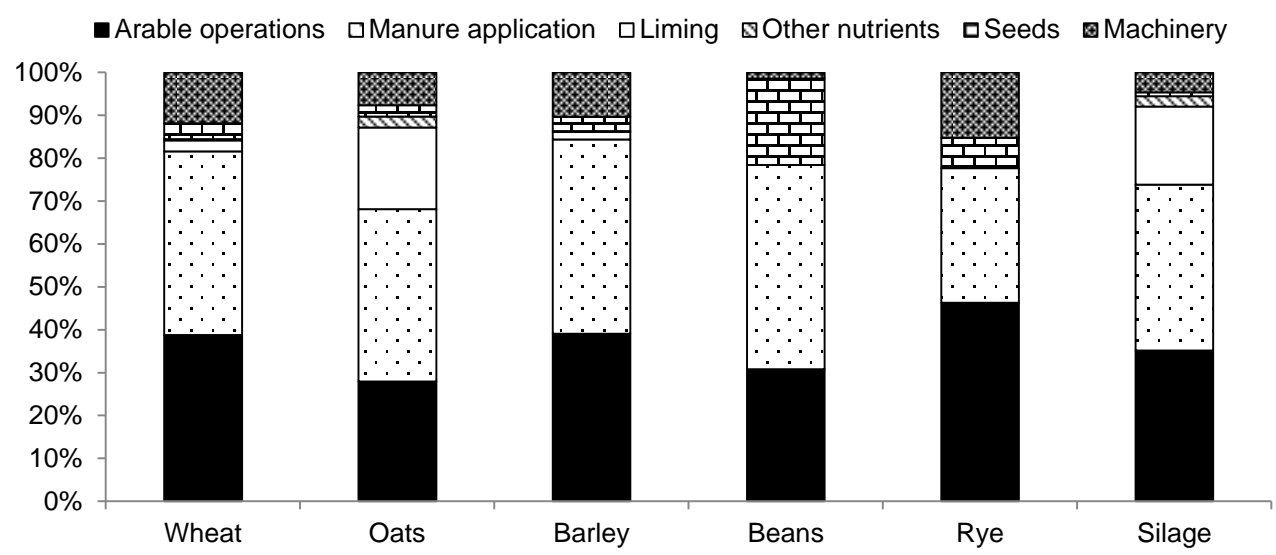

Figure 6 Contribution of different farming operations to global warming potential of arable crops [The results refer to the seven-year rotation cycle. Arable operations: GHG emissions from production and use of diesel by farm machinery and for drying of seeds after harvest. Manure application: direct and indirect $\mathrm{N}_{2} \mathrm{O}$ emissions from use of FYM and slurry. Liming: $\mathrm{CO}_{2}$ emissions from application of lime to land. Other nutrients: manufacture and transport of lime and trace minerals. Seeds: cultivation and transport of seeds.]

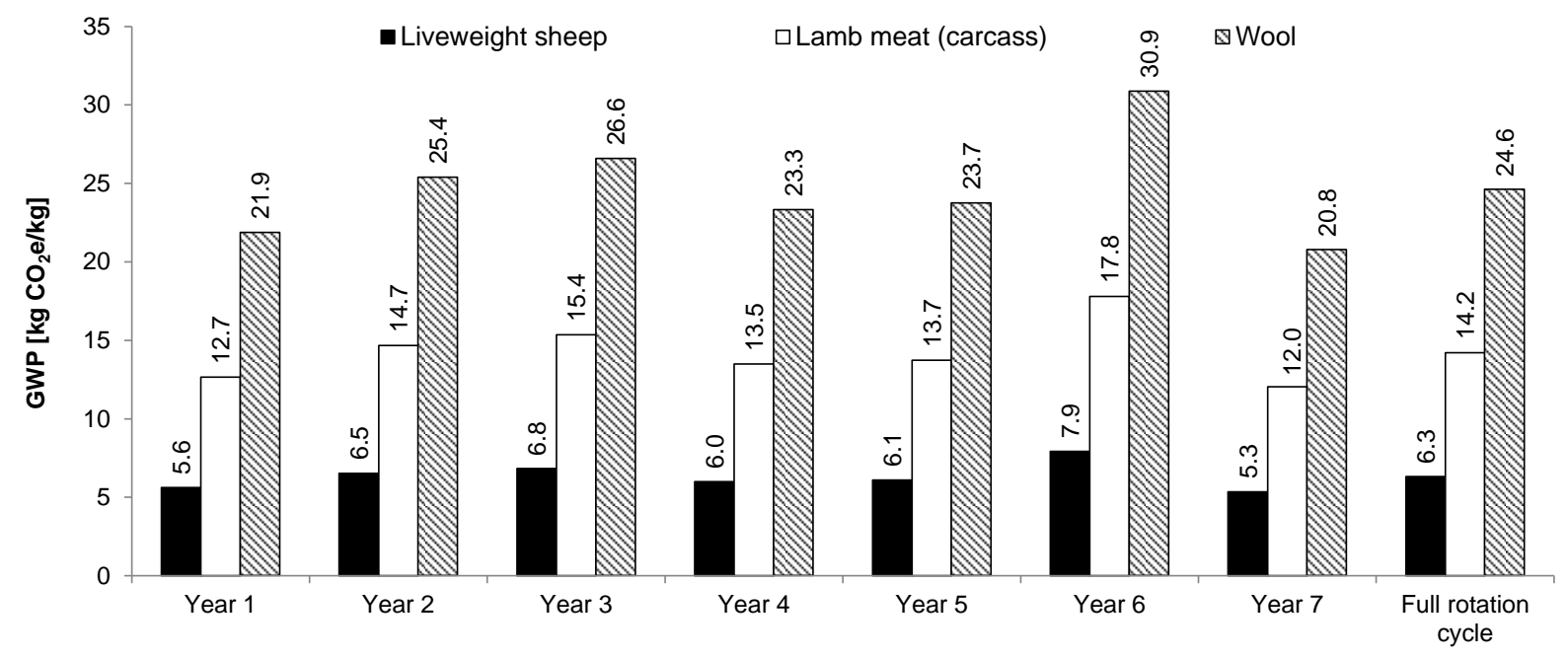

Figure 7 Global warming potential (GWP) of sheep (including lambs), lamb meat and wool over the rotation cycle

[GWP for each product obtained by dividing the GWP values in Table S12 by the total amount of products produced annually and over the full rotation period (Table 7), respectively.]

\subsection{Sheep and lamb husbandry unit}

GHG emissions associated with the sheep and lamb husbandry unit are summarised in Figure 7. GWP per $\mathrm{kg}$ of liveweight sheep (including lambs) ranges from 5.3-7.9 $\mathrm{kg} \mathrm{CO}_{2} \mathrm{e}$, averaging $6.3 \mathrm{~kg} \mathrm{CO} 2 \mathrm{e}$ over the rotation cycle. Per $\mathrm{kg}$ of lamb meat (carcass), the emissions vary from $12-17.8 \mathrm{~kg} \mathrm{CO}_{2} \mathrm{e}$, with an overall average of $14.2 \mathrm{~kg} \mathrm{CO} 2$. The main reason for the variation is the difference in the number of lambs reared per ewe each year. The GWP of wool ranges from $20.8-30.9 \mathrm{~kg} \mathrm{CO} \mathrm{CO}_{2} \mathrm{e} / \mathrm{kg}$, averaging 2.4.6 $\mathrm{kg} \mathrm{CO} 2 \mathrm{e} / \mathrm{kg}$ over the rotation cycle.

$\mathrm{CH}_{4}$ emissions from enteric fermentation and excreta deposition on land account on average for $73 \%$ of the total GWP from this unit, followed by the emissions of $\mathrm{N}_{2} \mathrm{O}$ from excreta (19\%). The contributions of grazing and feed concentrate are small (6\% and $2 \%$, respectively) and that of water is negligible. 


\subsection{Pig husbandry unit}

As indicated in Figure 8, the average GWP over the rotation cycle is estimated at $4.8 \mathrm{~kg} \mathrm{CO}_{2} \mathrm{e}$ per $\mathrm{kg}$ of liveweight pigs and $6.7 \mathrm{~kg} \mathrm{CO}$ eq. per $\mathrm{kg}$ of pork carcass meat. Similar to the other farm units, a wide annual variation in the emissions associated with pig rearing can be seen, from $3.9 \mathrm{~kg} \mathrm{CO}{ }_{2} \mathrm{e} / \mathrm{kg}$ liveweight in year 1 to $6 \mathrm{~kg} \mathrm{CO}_{2} \mathrm{e}$ in year 5 . In a similar manner, the impact per $\mathrm{kg}$ of pig meat varies from $5.6-8.5 \mathrm{~kg}$ $\mathrm{CO}_{2} \mathrm{e}$. The main reason for this is the annual variation in the number of piglets (see Table S5 in SI).

Two main contributors to the GWP from the pig husbandry unit are the feed concentrate $(53 \%)$ and $\mathrm{N}_{2} \mathrm{O}$ emissions from excreta deposition (27\%). Methane emissions from enteric fermentation and manure are responsible for $10 \%$ of the total GHG emissions, while the bedding accounts for $9 \%$.

\subsection{Beef cattle husbandry unit}

The GHG emissions associated with the beef cattle, shown in Figure 9, range from 8.6-10.3 $\mathrm{kg} \mathrm{CO} \mathrm{CO}_{2} \mathrm{e} / \mathrm{kg}$ liveweight and 15.8-18.9 $\mathrm{CO}_{2} \mathrm{e} / \mathrm{kg}$ beef (carcass), with an average of 9.7 and $17.7 \mathrm{~kg} \mathrm{CO} \mathrm{CO}_{2} \mathrm{e} / \mathrm{kg}$, respectively. The variation is due to the annual variation in the GWP of silage and feed crops as well as the variation in the number of calves reared. $\mathrm{CH}_{4}$ emissions are the largest contributor to the GWP, with $\sim 40 \%$ during winter (indoors period) and $\sim 50 \%$ over the summer months (outdoors). This is followed by $\mathrm{N}_{2} \mathrm{O}$ emissions in summer ( 30\%) and silage consumption during winter ( $\left.25 \%\right)$. The contribution of milk fed to calves varies over the year from $3 \%$ to $11 \%$, reflecting the number of calves in the herd and the calving periods. The grazing land causes up to $7 \%$ of the impact during summer.

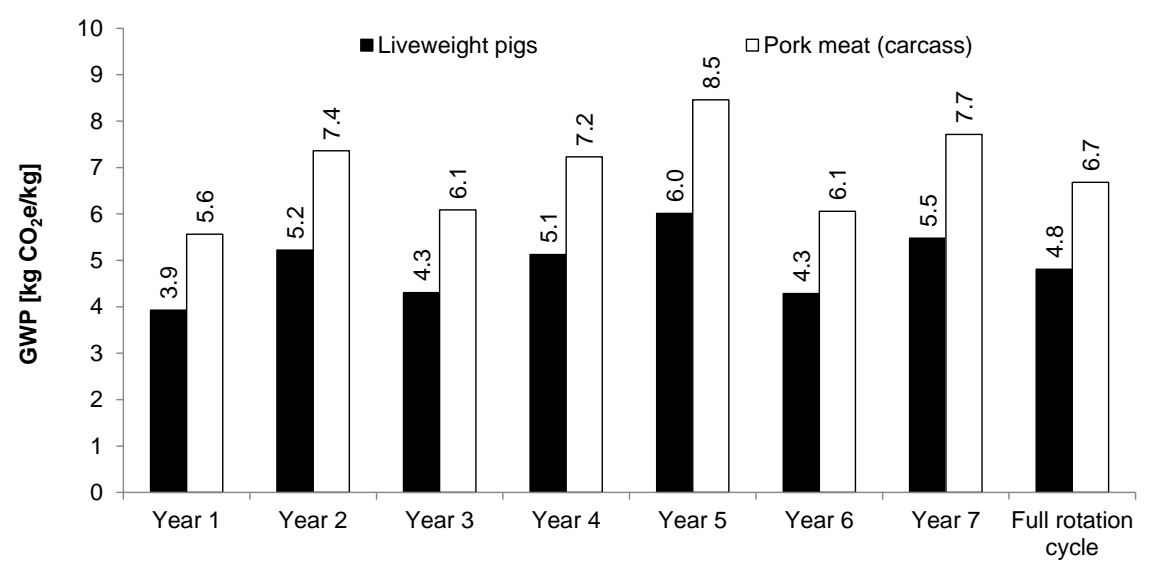

Figure 8 Global warming potential (GWP) of live pigs and pig meat over the rotation cycle

GWP for each product obtained by dividing the GWP values in Table S12 by the total amount of products produced annually and over the full rotation period (Table 7), respectively.]

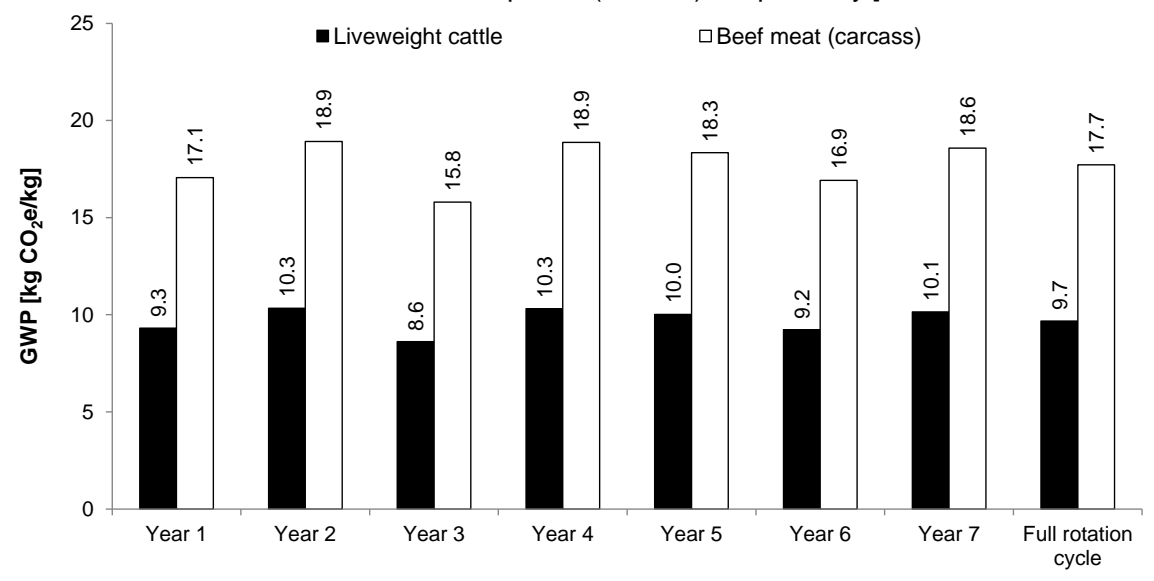

Figure 9 Global warming potential (GWP) of live cattle and beef meat over the rotation cycle [GWP for each product obtained by dividing the GWP values in Table $S 12$ by the total amount of products produced annually and over the full rotation period (Table 7), respectively.] 


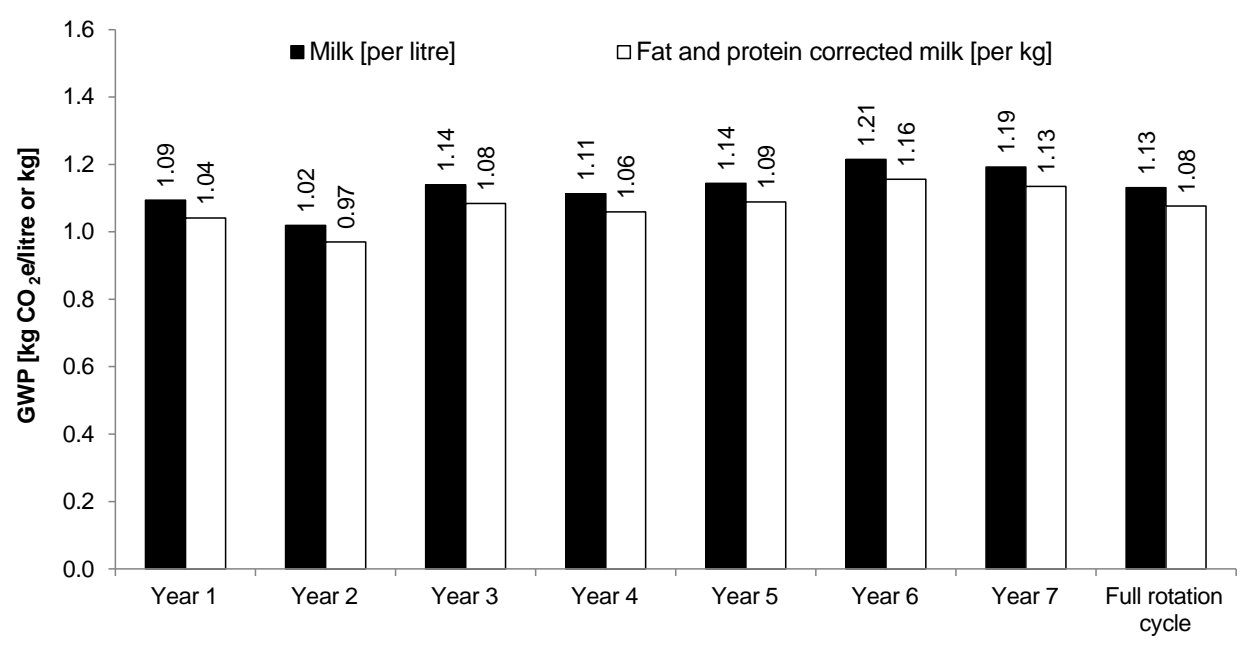

Figure 10 Global warming potential (GWP) of milk over the rotation cycle

GWP for milk obtained by dividing the GWP values in Table S12 by the total amount of milk produced annually and over the full rotation period (Table 7), respectively.]

\subsection{Dairy cattle unit}

The average GWP of milk production is estimated at $1.13 \mathrm{~kg} \mathrm{CO}_{2} \mathrm{e} / \mathrm{l}$, or $1.08 \mathrm{~kg} \mathrm{CO} 2 \mathrm{e} / \mathrm{kg}$ when corrected for the fat and protein content (Figure 10). Per litre of milk, the impact over the period ranges from 1.02 to $1.21 \mathrm{~kg} \mathrm{CO} 2$ e. $\mathrm{CH}_{4}$ emissions and silage contribute most to the impact during winter ( 60\%); it is also the largest contributor ( 40\%) in the summer period, together with the $\mathrm{N}_{2} \mathrm{O}$ emissions from excreta. Cows-inmilk have higher $\mathrm{CH}_{4}$ emissions during spring and summer when they produce the largest volumes of milk, since enteric fermentation depends on the feed intake, which is related to the amount of milk produced.

\subsection{Comparison of results with other studies}

The GWP estimated in this study is compared in Table 15 to the values found in the literature for organic products. As can be observed, the results in the literature vary widely due to numerous factors, such as different methodologies, allocation, geographical regions, farming practices, etc. Nevertheless, the findings from this study fall broadly within the reported ranges. The best agreement is found for spring barley, silage, pigs and pig meat, beef and milk. The values for the liveweight sheep, lamb meat and cattle are somewhat lower than in the literature while those for the spring beans are closer to the top end of the range reported in other studies. The allocation method is the main reason for the differences in the impact for sheep and lamb meat. In the reported studies, economic allocation was applied to allocate the impact between wool and meat, with only $2 \%$ allocated to the wool, while the biophysical allocation method used here allocates about $20 \%$ to the wool (Table 12).

The greatest difference in the results between this study and the literature is observed for winter wheat and rye, which have a much lower impact here; however, the ranges for winter and spring wheat compare well (Table 15). No GWP values were found in the literature for oats.

\subsection{Sensitivity analysis}

The parameters that could potentially affect the results include allocation of $\mathrm{N}$ and the related emissions of $\mathrm{N}_{2} \mathrm{O}$ over the rotation cycle as well as allocation of GHG emissions among the co-products. Therefore, these two parameters are considered in the sensitivity analysis. In addition to the base case considered so far, five scenarios have been developed for this purpose, with scenarios 1-3 related to the allocation of $\mathrm{N}$ and scenarios 4 and 5 to the allocation of GHG emissions among the co-products.

Table 16 summarises the assumptions for scenarios 1-3. In Scenario $1, \mathrm{~N}$ (and $\mathrm{N}_{2} \mathrm{O}$ emissions) is allocated on the basis of the $\mathrm{N}$ requirement of the crops as detailed in a fertiliser manual (DEFRA, 2009b). In Scenario 2, they are equally allocated among the crops over the seven-year rotation period, while in Scenario 3 they are fully allocated to the crop applied and none to the any other crops later in the cycle. The remaining two scenarios consider allocation of GHG emissions among the co-products using a 
mass basis (Scenario 4) and economic values (Scenario 5), instead of the biophysical allocation used in the base case (see Table 17). The allocation factors used are detailed in S13-14 in SI.

The results of the sensitivity analysis for all five scenarios are shown in Figure 11 and Figure 12 for crops and animal products, respectively. These are discussed in the next sections.

Table 15 Comparison of global warming potential for different organic agricultural products estimated in this and some other studies

\begin{tabular}{|c|c|c|c|c|}
\hline Product & Unit & $\begin{array}{l}\text { This study: } \\
\text { range (average) }\end{array}$ & $\begin{array}{l}\text { Other studies: } \\
\text { range (average) }\end{array}$ & Source \\
\hline Winter milling wheat & $\mathrm{g} \mathrm{CO}_{2} \mathrm{e} / \mathrm{kg}$ & 183-392 (232) & $460-790(625)$ & $\begin{array}{l}\text { DEFRA (2009b), Williams et al. (2006), } \\
\text { Ecoinvent (2014) }\end{array}$ \\
\hline Spring wheat & $\mathrm{g} \mathrm{CO}_{2} \mathrm{e} / \mathrm{kg}$ & - & $170-550(360)$ & Bos et al. (2014), Agri-BALYSE (2014) \\
\hline Spring oats & $\mathrm{g} \mathrm{CO}_{2} \mathrm{e} / \mathrm{kg}$ & $240-543(369)$ & & This study \\
\hline Winter barley & $\mathrm{g} \mathrm{CO}_{2} \mathrm{e} / \mathrm{kg}$ & - & $360-390(375)$ & Ecoinvent (2014) \\
\hline Spring barley & $\mathrm{g} \mathrm{CO}_{2} \mathrm{e} / \mathrm{kg}$ & $269-745(350)$ & $300-390(345)$ & Knudsen et al. (2014) \\
\hline Spring beans & $\mathrm{g} \mathrm{CO}_{2} \mathrm{e} / \mathrm{kg}$ & 525-1567 (692) & $290-710(470)$ & $\begin{array}{l}\text { Agri-BALYSE (2014), Bos et al. (2014), } \\
\text { Ecoinvent (2014) }\end{array}$ \\
\hline Rye & $\mathrm{g} \mathrm{CO}_{2} \mathrm{e} / \mathrm{kg}$ & $111-199(157)$ & $350-360(355)$ & Ecoinvent (2014) \\
\hline Silage & $\mathrm{g} \mathrm{CO}_{2} \mathrm{e} / \mathrm{kg}$ & $113-211(166)$ & $120-170(145)$ & $\begin{array}{l}\text { DEFRA (2009b), Bos et al. (2014), } \\
\text { Ecoinvent (2014) }\end{array}$ \\
\hline Straw & $\mathrm{g} \mathrm{CO}_{2} \mathrm{e} / \mathrm{kg}$ & 98-154 (128) & 60 & Ecoinvent (2014) \\
\hline Sheep (liveweight) & $\mathrm{kg} \mathrm{CO}{ }_{2} \mathrm{e} / \mathrm{kg}$ & $5.3-7.9(6.3)$ & $4.6-14.7(9.7)$ & Williams et al. (2006); DEFRA (2009b) \\
\hline Lamb meat (carcass) & $\mathrm{kg} \mathrm{CO} 2 \mathrm{e} / \mathrm{kg}$ & $12-17.8(14.2)$ & $10.1-27(18.6)$ & Williams et al. (2006); DEFRA (2009b) \\
\hline Pigs (liveweight) & $\mathrm{kg} \mathrm{CO} 2 \mathrm{e} / \mathrm{kg}$ & $4-6.1(4.8)$ & $2.4-7.6(5)$ & $\begin{array}{l}\text { Agri-BALYSE (2014), DEFRA } \\
\text { (2009b),Dourmad et al. (2014), Basset- } \\
\text { Mens and van der Werf (2005), } \\
\text { Halberg et al. (2010) }\end{array}$ \\
\hline Pig meat (carcass) & $\mathrm{kg} \mathrm{CO}{ }_{2} \mathrm{e} / \mathrm{kg}$ & $5.6-8.5(6.7)$ & $4.0-9.9(6.95)$ & $\begin{array}{l}\text { DEFRA (2009b), Williams et al. (2006), } \\
\text { Kool et al. (2009) }\end{array}$ \\
\hline Cattle (liveweight) & $\mathrm{kg} \mathrm{CO}{ }_{2} \mathrm{e} / \mathrm{kg}$ & $8.7-10.4(9.7)$ & $11.1-23.2(17.2)$ & $\begin{array}{l}\text { The National Trust (2012), de Vries et } \\
\text { al. (2015), Casey and Holden (2006) }\end{array}$ \\
\hline Beef meat (carcass) & $\mathrm{kg} \mathrm{CO}{ }_{2} \mathrm{e} / \mathrm{kg}$ & $15.8-18.9(17.7)$ & $11.6-32(21.8)$ & $\begin{array}{l}\text { DEFRA (2009b), Peters et al. (2010), } \\
\text { Williams et al. (2006) }\end{array}$ \\
\hline \multirow[t]{2}{*}{ Milk } & $\begin{array}{l}\mathrm{kg} \mathrm{CO} \mathrm{CO}_{2} / \mathrm{l} \text { milk } \\
\mathrm{kg} \mathrm{CO} \mathrm{CO}_{2} \mathrm{e} / \mathrm{kg} \text { milk }\end{array}$ & $\begin{array}{l}1.08-1.28(1.19) \\
1.05-1.24(1.16)\end{array}$ & $\begin{array}{l}1.2-1.3(1.25) \\
1.3-1.6(1.45)\end{array}$ & $\begin{array}{l}\text { DEFRA (2009b), Williams et al. (2006), } \\
\text { Haas et al. (2001), Bos et al. (2014), } \\
\text { Kiefer et al. (2014) }\end{array}$ \\
\hline & $\mathrm{kg} \mathrm{CO}{ }_{2} \mathrm{e} / \mathrm{kg} \mathrm{FPCM}$ & $1.03-1.22(1.13)$ & $0.8-1.5(1.15)$ & $\begin{array}{l}\text { Agri-BALYSE (2014), Bos et al. (2014), } \\
\text { Thomassen et al. (2008), Hietala et al. } \\
\text { (2015) }\end{array}$ \\
\hline
\end{tabular}

Table 16 Scenarios for different allocation of nitrogen

\begin{tabular}{lll}
\hline Base case and scenarios & Allocation basis & Details \\
\hline Base case & N mineralisation & As in Table 12 \\
N requirement of crop & $\begin{array}{l}\text { Assuming N requirements of crops as per fertiliser } \\
\text { manual (see Table S15 in SI) }\end{array}$ \\
2 & $\begin{array}{l}\text { Equally among the crops in } \\
\text { rotation over seven years } \\
\text { Allocated to the crop applied }\end{array}$ & $\begin{array}{l}\text { residue and cove crops } \\
\text { FYM and slurry: } 100 \% \text { to the crop applied; crop residue } \\
\text { and cover crops: } 100 \% \text { to the subsequent crop }\end{array}$ \\
\hline
\end{tabular}

Table 17 Scenarios for mass and economic allocation between the co-products

\begin{tabular}{lll}
\hline Base case and scenarios & Allocation basis & Details \\
\hline Base case & Biophysical & As in Table 12 \\
4 & Economic & See allocation factors in Table S13 in SI \\
5 & Mass & See allocation factors in Table S14 in SI \\
\hline
\end{tabular}




\subsubsection{Allocation of $\mathrm{N}$ and $\mathrm{N}_{2} \mathrm{O}$ emissions (Scenarios 1-3)}

As shown in Figure 11, the average GWP of the beans decreases by $50 \%$ compared to the base case if all nitrogen and the related $\mathrm{N}_{2} \mathrm{O}$ emissions from slurry, manure, cover crops and crop residue are allocated on the basis of crop $\mathrm{N}$ requirements (Scenario 1). In this case, there is also a decrease in the average GWP of oats and barley by $10 \%$ and $20 \%$, respectively. This in turn leads to a $13 \%$ increase in the impact from wheat and $11 \%$ from both rye and silage. This is because beans do not need $\mathrm{N}$ fertiliser, while oats and barley have lower fertiliser requirements compared to wheat and grass (as detailed in Table S15 in SI). If, on the other hand, $\mathrm{N}$ is allocated equally among crops over seven years (Scenario 2), the reduction in the impacts from beans, oat and barley is smaller (3\%-13\%) compared to the base case. However, the impact from rye goes up by $22 \%$ compared to the base case. This is due to rye being the last crop in the rotation cycle (planted in year 7) and having a lower allocation of $\mathrm{N}$ in the base case (as detailed in Table 12). In Scenario 3, the impact of silage is higher by $8 \%$ while that of all other crops is lower by $5 \%-10 \%$, with the greatest reduction relative to the base case found for the crops planted later in the rotation cycle.

Allocation of $\mathrm{N}$ and $\mathrm{N}_{2} \mathrm{O}$ emissions also affects the impact from the livestock and the related products, largely because of the silage and crops used as feed and straw as bedding; thus, the GWP variation pattern is similar to that of silage. However, the effect is less pronounced than for the silage because of the high contribution of $\mathrm{CH}_{4}$ to the total GWP of sheep and cattle. For milk, beef, lamb and wool, there is an increase of $1 \%-2 \%$ in the GWP in Scenarios $1-3$. For pigs, the impact is very slightly lower $(0.4 \%$ $0.7 \%$ ) which is due to the straw bedding as they are fed by concentrate rather than by silage.

Therefore, these results highlight the importance of considering $N$ over the rotation cycle and how it affects the interconnected units at a farm. The importance of this has also been pointed out by FAO (2016b). Hence, rather than simplifying the calculation of $\mathrm{N}_{2} \mathrm{O}$ emissions by averaging $\mathrm{N}$ inputs over the fields in the rotation, and thus ignoring the complexity ruling the physical transfer of nitrogen from one year to the next, this study has explored a way to address this complexity by considering the farm as a whole system over a full rotation cycle. These findings suggest that there is a need to develop guidelines on how to allocate $\mathrm{N}$ (and $\mathrm{N}_{2} \mathrm{O}$ ) emissions in crop rotations as these choices have significant effect on the GWP of crops.

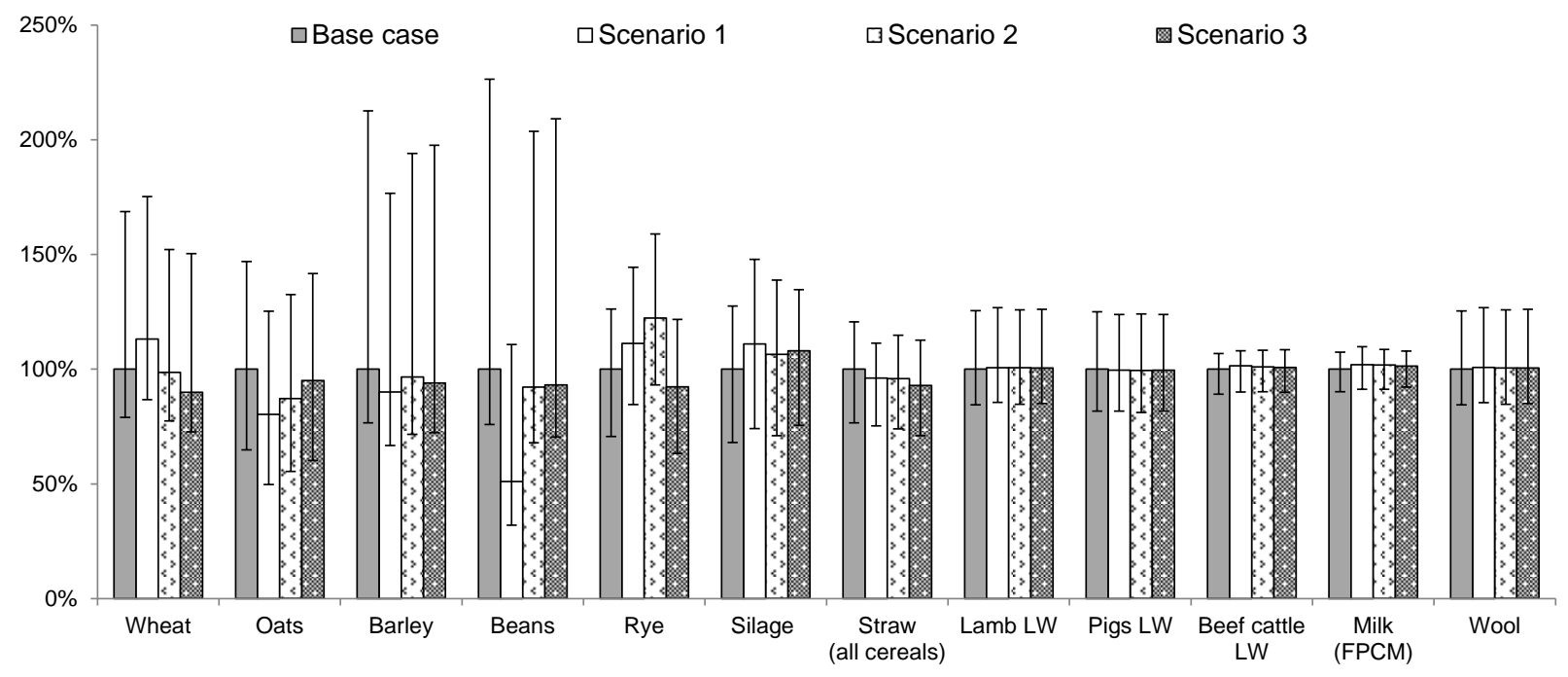

Figure 11 The effect of nitrogen allocation on global warming potential of different farm products 


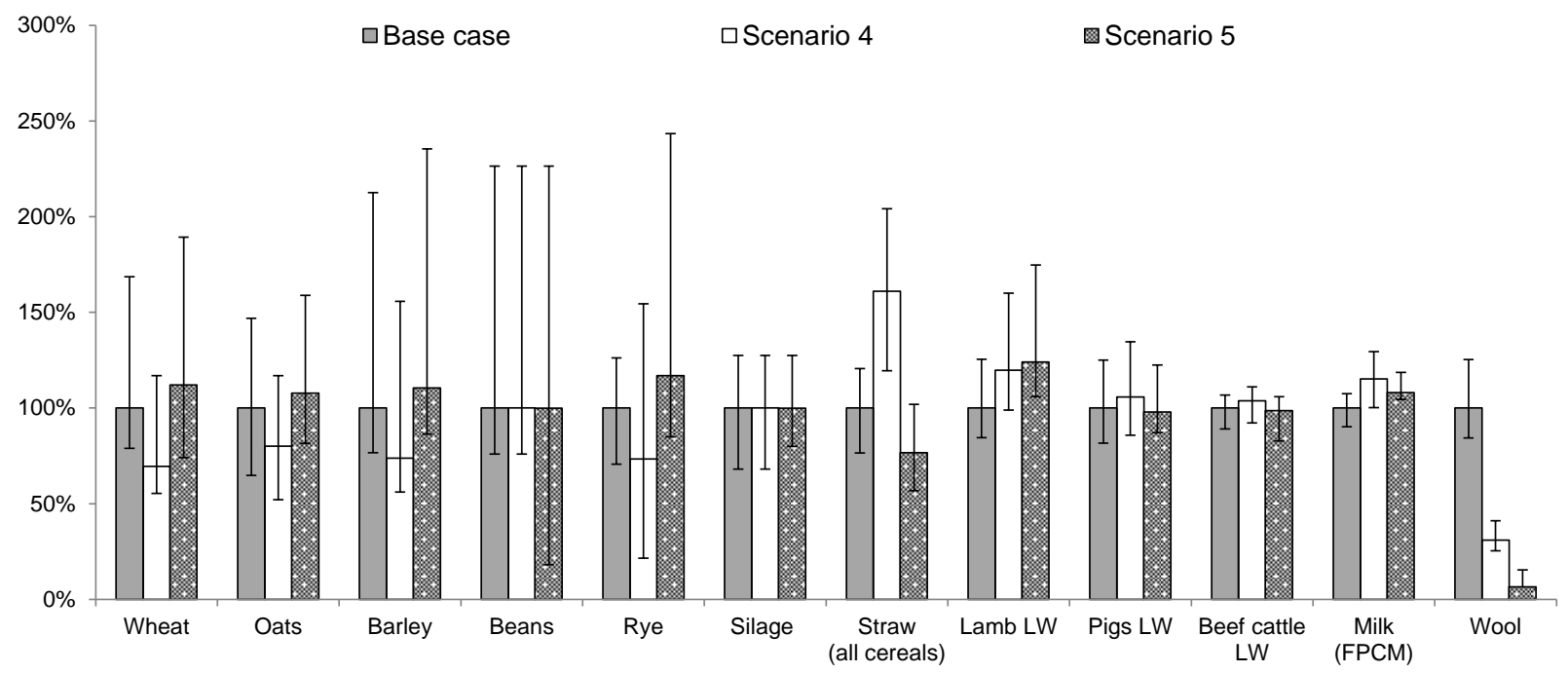

Figure 12 Effects of co-product allocation on GWP on farm products

\subsubsection{Allocation of GHG emissions (Scenarios 4 and 5)}

The choice of the allocation method for GHG emissions has a considerable effect on the GWP of wheat, oats, barley, rye and straw (Figure 12). Compared to the base case, the impact for these crops is reduced by up to $30 \%$ if mass allocation (Scenario-4) is applied instead of the biophysical. Conversely, the GWP of straw increases significantly (by 60\%), because the mass allocation factors for straw are much higher than in biophysical allocation (see Table S13 in SI). On the other hand, the economic allocation factors for straw are lower (Table S14); therefore, the GWP of straw is $23 \%$ lower in Scenario 5, while the impact of wheat, oats, barley and rye is $8 \%-17 \%$ higher relative to the base case. Beans and silage are not affected because they are not associated with any of the crop co-products.

The choice of the allocation method also has a significant effect on the GWP of lamb, wool and milk. If mass or economic allocation is applied, the GWP of wool is reduced by up to $93 \%$ and the impact of milk and lamb increases by up to $15 \%$ and $24 \%$, respectively, relative to the base case. Pigs and beef show a relatively lower sensitivity to the allocation of GHG emissions, which are mainly due to the straw used as bedding.

\subsection{Improvement opportunities}

Organic farms with integrated crop-livestock systems, such as the one considered in this work, already incorporate a range of practices aimed at high nutrient recycling and reduction of environmental impacts. This section discusses further opportunities for reducing GHG emissions from organic agriculture, focusing on the hotspots identified in the study: emissions of $\mathrm{N}_{2} \mathrm{O}$ and $\mathrm{CH}_{4}$ from manure and enteric fermentation as well as $\mathrm{CO}_{2}$ from combustion of diesel used in farm machinery. The options discussed here are relevant not only to this but to other integrated organic farms.

Emissions of $\mathrm{N}_{2} \mathrm{O}$ from manure and the related GWP can be reduced by intercropping, i.e. growing two or more crop species on the same plot of land (Jensen et al., 2015). Intercropping enhances the efficiency of nitrogen utilisation by crops, which in turn reduces its losses to the environment as $\mathrm{N}_{2} \mathrm{O}$. Better utilisation of nitrogen also helps to increase crop yields and reduce land requirements. Furthermore, by growing suitable crops together, intercropping can also aid pest and weed control (Jensen et al., 2015).

Further reductions in $\mathrm{N}_{2} \mathrm{O}$ emissions from manure can be achieved by reducing excretion of $\mathrm{N}$ by livestock. This can be regulated by modifying the composition of the feed. For example, improved types of pig concentrates are available that reduce $\mathrm{N}$ excretion, while at the same time having better feed-togrowth conversion rates (Kool et al. 2009). Modifying the feed can also be used to reduce $\mathrm{CH}_{4}$ emissions from enteric fermentation (Leytem and Dugan, 2014; Knapp et al., 2014). For example, adding whole 
cottonseeds to the concentrate improves its digestibility, which in turn reduces generation of $\mathrm{CH}_{4}($ Hietala et al., 2015).

Emissions of $\mathrm{CH}_{4}$ from manure can be reduced by treating it, together with crop residues, in anaerobic digestion (AD). The produced digestate can be used to improve nutrient management, particularly as it converts the organically-bound $\mathrm{N}$ in the manure to ammonium form, which is more readily available to crops (Tuomisto et al., 2012a). It also contains residual carbon, phosphorous and trace nutrients. Furthermore, biogas can be used to generate heat or electricity. Previous studies (e.g. Whiting and Azapagic, 2014; Fusi et al., 2016) have shown that utilisation of biogas can lead to significant reductions in GWP and other environmental impacts compared to using fossil fuels. However, care must be taken to minimise ammonia emissions from digestate and the related acidification and eutrophication potentials (Fusi et al., 2016).

Substituting diesel with biodiesel in farm machinery could also help to reduce GWP from integrated organic systems. For example, using rape methyl ester (RME) can decrease the impact by $72 \%$ relative to diesel if RME is produced at the farm from rapeseed cultivated as part of crop rotation (Fredriksson et al., 2006; Hansson et al., 2007). However, this leads to an increase in acidification (by $30 \%$ ) and eutrophication (by a factor of five) compared to diesel. If, on the other hand, Fischer-Tropsch diesel produced from straw is used instead, GWP can be reduced by $94 \%$ without increasing acidification and eutrophication (Ahlgren et al., 2008).

\section{Conclusions}

This study has estimated GWP associated with cultivation of organic arable crops, livestock and their products at a large integrated organic farm in the UK. A seven-year rotation cycle has been considered, starting with clover leys in the first three years and followed in the consecutive years by wheat, oats, beans and barley, and finally rye. The farm rears pigs, sheep, dairy and beef cattle and produces related meat products, milk and wool.

The findings indicate that GWP varies significantly over the rotation cycle, both for the whole farm and the individual products. For the whole farm, it ranges from 1816 to $2372 \mathrm{t} \mathrm{CO}_{2} \mathrm{e} / \mathrm{yr}$, averaging at $2118 \mathrm{t} \mathrm{CO}_{2}$ eq./yr or 2.65 tonnes $\mathrm{CO}_{2} \mathrm{e} / \mathrm{ha}$. The main contributors are the dairy and beef cattle, causing $45 \%$ and $39 \%$ of the impact, respectively. Crop cultivation adds a further $10 \%$ and sheep rearing $6 \%$. The pigs herd, which is relatively small in size, contributes less than $1 \%$ to the total GWP.

The impact from the individual crops also ranges widely, with the maximum values being between 1.8 and three times higher (rye and beans, respectively) than the minimum over the rotation period. The highest average GWP is found for beans $\left(692 \mathrm{~g} \mathrm{CO}_{2} \mathrm{e} / \mathrm{kg}\right)$ and the lowest for rye $\left(157 \mathrm{~g} \mathrm{CO}_{2} \mathrm{e} / \mathrm{kg}\right)$. The average impact over the rotation cycle from barley, oats and wheat is estimated at 350,369 and $232 \mathrm{~g} \mathrm{CO}{ }_{2} \mathrm{e} / \mathrm{kg}$, respectively. By comparison, silage and straw have a relatively low GWP (166 and $128 \mathrm{~g} \mathrm{CO}_{2} \mathrm{e} / \mathrm{kg}$ ). The major hotspots for the crops are $\mathrm{N}_{2} \mathrm{O}$ emissions from manure application and $\mathrm{CO}_{2}$ emissions from diesel used in the farm machinery.

Similar to the crops, there is a wide annual variation in the GHG emissions associated with the livestock and the related products. The GWP of sheep rearing ranges from 5.3-7.9 $\mathrm{kg} \mathrm{CO}_{2} \mathrm{e} / \mathrm{kg}$ liveweight, averaging $6.3 \mathrm{~kg} \mathrm{CO} 2 \mathrm{e}$ over the rotation cycle. Per $\mathrm{kg}$ of lamb meat (carcass), the emissions vary from $12-17.8 \mathrm{~kg} \mathrm{CO} 2 \mathrm{e}$, with an overall average of $14.2 \mathrm{~kg} \mathrm{CO} 2 \mathrm{e}$. The average GWP of wool is estimated at $24.6 \mathrm{~kg} \mathrm{CO} 2 \mathrm{e} / \mathrm{kg}$. The impact from beef cows is in the range of 8.6-10.3 $\mathrm{kg} \mathrm{CO} \mathrm{CO}_{2} \mathrm{e} / \mathrm{kg}$ liveweight, with the average value of $9.7 \mathrm{~kg} \mathrm{CO} 2$. The consequent $\mathrm{CO}_{2} \mathrm{e}$ emissions associated with beef vary from 15.8-18.9 $\mathrm{kg}$ per $\mathrm{kg}$ of carcass meat, averaging $17.7 \mathrm{~kg} \mathrm{CO} \mathrm{CO}_{2} \mathrm{e} / \mathrm{kg}$. For pigs, the impact varies from 3.9 to $6 \mathrm{~kg}$ $\mathrm{CO}_{2} \mathrm{e} / \mathrm{kg}$ liveweight and for pig meat from $5.6-8.5 \mathrm{~kg} \mathrm{CO}_{2} \mathrm{e} / \mathrm{kg}$ (average of $6.7 \mathrm{~kg} \mathrm{CO} \mathrm{CO}_{2} \mathrm{e} / \mathrm{kg}$ ).

Methane emissions from enteric fermentation and excreta deposition on land are the main contributors to the GWP of beef cattle and sheep, while the feed concentrate is responsible for the impact from pigs. Methane emissions are also the main cause of GWP for milk, which ranges from $1.02-1.21 \mathrm{~kg} \mathrm{CO} \mathrm{CO}_{2}$ e/l, with an overall average of $1.13 \mathrm{~kg} \mathrm{CO}$ e/l. 
The sensitivity analysis shows that the results are affected by assumptions for allocation of $\mathrm{N}$ and the related $\mathrm{N}_{2} \mathrm{O}$ emissions over the rotation cycle. If all $\mathrm{N}$ and the $\mathrm{N}_{2} \mathrm{O}$ emissions from slurry manure, cover crops and crop residue are allocated on the basis of crop $\mathrm{N}$ requirements, the GWP of oats, barley and beans decreases by $10 \%$ (oats) to $50 \%$ (beans) compared to the base case (where $\mathrm{N}$ is allocated over seven years based on the $\mathrm{N}$ mineralisation rate). This in turn increases the impact from wheat, silage and rye by up to $13 \%$. If $\mathrm{N}$ is allocated to year 1 in the rotation cycle instead, the average GWP of silage is higher by $8 \%$, while the impact of all other crops is lower by $5 \%-10 \%$, with the greatest reduction relative to the base case found for the crops planted later in the rotation cycle. The allocation of $\mathrm{N}$ also affects the impact from the livestock and their products, with the pattern similar to that of silage, largely because of its use as feed.

The results of the sensitivity analysis also suggest that the allocation method for the crop co-products (grain and straw) has a considerable effect on the GWP of wheat, oats, barley, rye and straw. The impact from these crops reduces by up to $30 \%$ if mass allocation is applied instead of the biophysical basis used in the base case. Conversely, the GWP of straw increases by $60 \%$. On the other hand, in the case of economic allocation, the GWP of straw is $23 \%$ lower, while the impact of wheat, oats, barley and rye is $8 \%-17 \%$ higher relative to the base case. Similarly, the choice of the allocation method has a significant effect on the GWP of lamb, wool and milk. If mass or economic allocation is applied, the GWP of wool is reduced by up to $93 \%$ and the impact of milk and lamb increases by up to $24 \%$ compared to the base case.

Therefore, these results highlight the importance of considering integrated farms, such as the one studied here, as whole systems, taking into account a full rotation cycle. This ensures not only that the estimates of environmental impacts are more representative of the complex interconnections between different subsystems within a farm, but also helps identify the benefits of improvement opportunities at a systems level, in congruence with the principles of integrated organic farming.

\section{Acknowledgements}

This study was funded by the UK Engineering and Physical Sciences Research Council (EPSRC, Grant no. EP/K011820/1) which is gratefully acknowledged. The authors would also like to thank the following people and organisations for the data, advice and comments: David Wilson (Duchy Home Farm), Keith Preston, Richard Bower and Sarah Pauling (Savills) and Mark Measures (Institute of Organic Farming and Advice). We are also grateful to the two anonymous reviewers for their constructive and wellinformed comments which have helped us to improve the paper.

\section{References}

Agri-BALYSE Program, 2014. Agri-BALYSE database, v.1.1, ADEME, Angers.

Ahlgren, S., A. Baky, S. Bernesson, Å. Nordberg, O. Norén, P.A. Hansson, 2008. Future fuel supply systems for organic production based on Fischer-Tropsch diesel and dimethyl ether from on-farmgrown biomass. Biosystems Engineering 99, 145-155.

AHDB, 2017. The cereals directory, Agriculture and Horticulture Development Board. http://beefandlamb.ahdb.org.uk/.

AHDB. 2014. Greenhouse gas emissions on British dairy farms, DairyCo carbon foot printing study: Year three (2012-2013) report.

Audsley E., Alber, S., Clift, R., Cowell, S., Crettaz, P., Gaillard, G., Hausheer, J., Jolliet, O., Kleijn, R., Mortensen, B., Pearce, D., Roger, E., Teulon, H., Weidema, B., Van Zeijts, H., 1997. Harmonisation of environmental life cycle assessment for agriculture, Final report, Concerted Action AIR3-CT94-2028, European Commission, DG VI.

Basset-Mens, C., H.M.G. van der Werf, 2005. Scenario-based environmental assessment of farming systems: the case of pig production in France, Agric., Ecosystems and Environ., 105, 127-144.

Blonk Agri-footprint BV, 2015. Agri-footprint description of data - version 2.0. www.agri-footprint.com" www.agri-footprint.com.

Bos, J.F.F.P., J. de Haan, W. Sukkel, R.L.M. Schils, 2014. Energy use and greenhouse gas emissions in organic and conventional farming systems in the Netherlands. NJAS - Wageningen Journal of Life Sciences, 68, 61-70. 
Brankatschk, G., M. Finkbeiner, 2015. Modeling crop rotation in agricultural LCAs—challenges and potential solutions. Agric. Syst., 138, 66-76.

Brankatschk, G., M. Finkbeiner, 2014. Application of the Cereal Unit in a new allocation procedure for agricultural life cycle assessments. J. Clean. Prod. 73, 72-79.

BSI, 2011. Publicly Available Specification PAS 2050:2011. Specification for the assessment of the life cycle greenhouse gas emissions of goods and services. British Standards Institution, London.

Casey, J.W., N.M. Holden, 2006. Greenhouse gas emissions from conventional, agri-environmental scheme, and organic Irish suckler-beef units.J.Environ. Qual.,35, 231-239.

CCaLC, 2013. CCaLC tool and database V3.3. The University of Manchester, www.ccalc.org.uk.

Cooper, J.M., G. Butler, C. Leifert, 2011. Life cycle analysis of greenhouse gas emissions from organic and conventional food production systems, with and without bioenergy options, NJAS - Wageningen J. Life Sci., 58, 185-192.

Department for Agriculture, Food and Rural Affairs (DEFRA), 2009a. Guidance for farmers in nitrate vulnerable zones. Leaflet 3, London.

Department for Agriculture, Food and Rural Affairs (DEFRA), 2009b. Scenario building to test and inform the development of a BSI method for assessing greenhouse gas emissions from food. Report to Defra, Project Reference Number: FO0404. ADAS, London.

Department for Agriculture, Food and Rural Affairs (DEFRA), 2010. Fertiliser manual (RB 209). $8^{\text {th }}$ edition. DEFRA, London.

Department for Environment, Food and Rural Affairs (DEFRA), 2014a. UK Government conversion factors for Company Reporting. DEFRA, London.

de Vries, M., C. Van Middelaar, I. De Boer, 2015. Comparing environmental impacts of beef production systems: A review of life cycle assessments, Livest. Sci., 178, 278-288.

Dourmad J.Y., J. Ryschawy, T. Trousson, M. Bonneau, J. Gonzàlez, H.W. Houwers, M. Hviid, C. Zimmer, T.L. Nguyen, L. Morgensen, 2014. Evaluating environmental impacts of con-trasting pig farming systems with life cycle assessment. Animal, 8, 2027-2037.

EC, 2005. Reference document on best available techniques in the slaughterhouses and animal byproducts industries, European Commission. http://eippcb.jrc.ec.europa.eu/reference/sa.html.

Ecoinvent Centre, 2010. Swiss Centre for Life Cycle Inventories. Ecoinvent Database v 2.2. Dübendorf.

Ecoinvent Centre, 2014. Swiss Centre for Life Cycle Inventories. Ecoinvent Database v 3.1, Dübendorf.

Edwards, S., 2002. Feeding organic pigs: A handbook of raw materials and recommendations for feeding practice. University of Newcastle, Newcastle.

FAO, 2016a. Environmental performance of large ruminant supply chains: Guidelines for assessment. Livestock Environmental Assessment and Performance Partnership. FAO, Rome, Italy.

FAO, 2016b. Environmental performance of animal feeds supply chains: Guidelines for assessment. Livestock Environmental Assessment and Performance Partnership. FAO, Rome, Italy.

FAOSTAT, 2015. Emissions - agriculture. Rome,. http://faostat3.fao.org/browse/G1/*/E.

Fredriksson, H., A. Baky, S. Bernesson, A. Nordberg, O. Norén, P.A. Hansson. Use of on-farm produced biofuels on organic farms - evaluation of energy balances and environmental loads for three possible fuels. Agricultural Systems, 89(1) (2006) 184-203.

Fusi, A., J. Bacenetti, M. Fiala and A. Azapagic, 2016. Life cycle environmental impacts of electricity from biogas produced by anaerobic digestion. Frontiers in Bioengineering and Biotechnology, 4(26), 117.Gerber, P.J., H. Steinfeld, B. Henderson, A. Mottet, C. Opio, J. Dijkman, A. Falcucci, G. Tempio, 2013. Tackling climate change through livestock - A global assessment of emissions and mitigation opportunities. FAO, Rome.

Haas, G., F. Wetterich,U. Köpke, 2001. Comparing intensive, extensified and organic grassland farming in southern Germany by process life cycle assessment. Agric. Ecosystems and Environ.,83, 43-53.

Halberg N., J.E. Hermansen, I.S. Kristensen, J. Eriksen, N. Tvedegaard, B.M. Petersen, 2010. Impact of organic pig production systems on $\mathrm{CO} 2$ emission, $\mathrm{C}$ sequestration and nitrate pollution. Agron. Sustain. Dev. 30, 721-731.

Hanks J., M. Kossaibati, 2013. Key performance indicators for the UK national dairy herd in 2012, https://www.nmr.co.uk/uploads/files/files/ayrshire-51NMRherds-report-april2013.pdf

Hansson, P.A., A. Baky, S. Ahlgren, S. Bernesson,Å. Nordberg, O. Norén, O. Pettersson, 2007. Selfsufficiency of motor fuels on organic farms - evaluation of systems based on fuels produced in industrial-scale plants. Agricultural Systems, 94(3) 704-714. 
Hietala S., L. Smith, M.T. Knudsen, S. Kurppa, S. Padel, J.E. Hermansen, 2015. Carbon footprints of organic dairying in six European countries-real farm data analysis, Organic Agriculture, 5, 91-100.

IDF, 2015. A common carbon footprint methodology for the dairy sector - The IDF guide to life cycle assessment methodology, International Dairy Federation, Brussels.

IFOAM, 2008. Definition of organic agriculture. Proceedings of the General Assembly of the International Federation on Organic Agricultural Movements, Vignola, Italy, www.ifoam.org/en/organiclandmarks/definition-organic-agriculture.

IPCC, 2006. Intergovernmental Panel on Climate Change guidelines for national greenhouse gas inventories. Edited by S. Eggleston, L. Buendia, K. Miwa, T. Ngara and K. Tanabe. IGES, Japan.

ISO, 2006a. ISO 14040: Environmental management - life cycle assessment - principles and framework. ISO, Geneva.

ISO, 2006b. ISO 14044: Environmental management - life cycle assessment - requirements and guidelines. ISO, Geneva.

Jensen, E.S., L. Bedoussac, G. Carlsson, E. Journet, E. Justes, H. Hauggaard-Nielsen, 2015. Enhancing Yields in Organic Crop Production by Eco-Functional Intensification, Sustainable Agriculture Research, 4, 42-50.

Kiefer, L., F. Menzel, E. Bahrs, 2014. The effect of feed demand on greenhouse gas emissions and farm profitability for organic and conventional dairy farms, Journal of Dairy Science, 97, 7564 - 7574.

Kool, A., H., Blonk, T. Ponsioen, W. Sukkel,H. Vermeer, J. de Vries, R. Hoste, 2009. Carbon footprints of conventional and organic pork. Assessment of typical production systems in the Netherlands, Denmark, England and Germany. Blonk Milieduadvies and Wageningen University and Research Centre. Gouda - Wageningen.

Knapp, J.R., G.L. Laur, P.A. Vadas, W.P. Weiss, J.M. Tricarico, 2014. Enteric methane in dairy cattle production: Quantifying the opportunities and impact of reducing emissions, Journal of Dairy Science, 97(6)3231-3261.

Knudsen, M.T., J.E. Hermansen, J.E. Olesen, N.Chirinda, 2012. Estimating carbon footprints of individual crops in organic arable rotations, 8th International Conference on LCA in the Agri-Food Sector, St. Malo, 2-4 October 2012.

Knudsen, M.T., A. Meyer-Aurich, J.E. Olesen, N.Chirinda, J.E. Hermansen, 2014. Carbon footprints of crops from organic and conventional arable crop rotations - using a life cycle assessment approach. Journal of Cleaner Production, 64, 609-618.

Lampkin, N., M. Measures, S. Padel, 2008. 2009 Organic farm management handbook. Institute of Biological, Environmental and Rural Sciences, Aberystwyth University, Wales.

Leytem, A.B., R.S. Dungan, 2014. Livestock GRACEnet: a workgroup dedicated to evaluating and mitigating emissions from livestock production J. Environ. Qual., 43, 1101-1110.

Lynch, M. J., M. J. Mulvaney, S. C. Hodges, T. L.Thompson,W. E. Thomason, 2016. Decomposition, nitrogen and carbon mineralization from food and cover crop residues in the central plateau of Haiti. SpringerPlus, 5(1), 973.

Martínez-Blanco, J., J. Rieradevall, A. Antón, P. Muñoz, 2014. Multifunctionality-solving approaches of compost application in crop rotations, J. Clean. Prod., 64,384-395.

Martins, A., H. Kelly, J. Day, C. Stopes, H. Browning, S. Edwards, 2002. Optimising organic pig production. A guide to good practice. DEFRA, London.

Marton, S. M. R. R., A. Zimmermann, M. Kreuzer, G .Gaillard, 2016. Comparing the environmental performance of mixed and specialised dairy farms: the role of the system level analysed. J. Clean. Prod., 124, 73-83.

Meier, M.S., F. Stoessel, N. Jungbluth, R. Juraske, C. Schader, M. Stolze, 2015. Environmental impacts of organic and conventional agricultural products - are the differences captured by life cycle assessment? J. Environ. Manag., 149, 193-208.

Nemecek, T., D. Dubois, O. Huguenin-Elie, G. Gaillard, 2011. Life cycle assessment of Swiss farming systems: I. Integrated and organic farming. Agricultural Systems, 104, 217-232.

Nemecek,T., F. Hayer, E. Bonnin, B. Carrouée, A. Schneider, C. Vivier,2015. Designing eco-efficient crop rotations using life cycle assessment of crop combinations, European Journal of Agronomy, 65, 40-51.

Niggli, U., H. Schmid, A. Fließach, 2008. Organic farming and climate change. Technical paper, International Trade Centre.

Niggli, U., A. Fließach, P. Hepperly, N. Scialabba, 2009. Low greenhouse gas agriculture. Mitigation and adaptation potential of sustainable farming systems. FAO, Rome. 
Olivier, J.G.J., G. Janssens-Maenhout, J.A.H.W. Peters, 2012. Trends in global CO2 emissions, 2012 report. Netherlands Environmental Assessment Agency; edgar.jrc.ec.europa.eu/CO2REPORT2012. pdf.

Panda, H. Integrated organic farming handbook. Asia Pacific Business Press Inc., New Delhi, India, 2013, $1-472$.

Peters, G.M., H.V. Rowley, S. Wiedemann, R. Tucker, M.D. Short, M. Schulz, 2010. Red meat production in Australia: life cycle assessment and comparison with overseas studies. Environ. Sci. Technol. 44, 1327-1332.

Peter,C., X. Specka, J. Aurbacher, P. Kornatz, C. Herrmann, M. Heiermann, J. Müller, C. Nendel, 2017. The MiLA tool: Modeling greenhouse gas emissions and cumulative energy demand of energy crop cultivation in rotation, Agricultural Systems, 152, 67-79.

Peyrauda, J.L., M. Taboadac, L. Delabya, 2014. Integrated crop and livestock systems in Western Europe and South America: A review. European Journal of Agronomy, 57, 31-42. Ponti, T., B. Rijk, M.K. van Ittersum, 2012. The crop yield gap between organic and conventional agriculture, Agricultural Systems, 108, 1-9.

Roy, P., D. Nei, T. Orikasa, Q. Xu, H. Okadome, N. Nakamura, T. Shiina, 2009. A review of life cycle assessment (LCA) on some food products. Journal of Food Engineering 90, 1-10.

Styles, D., J. Gibbons, A.P. Williams, J. Dauber, H. Stichnothe, B. Urban, D. R. Chadwick, D. L. Jones, 2015. Consequential life cycle assessment of biogas, biofuel and biomass energy options within an arable crop rotation. Global Change Biology Bioenergy, 7(6), 1305-1320.

Sullivan, D.M. Estimating plant-available nitrogen from manure, 2008. Oregon State University Extension Publication, EM8954-E. Oregon University, State USA, https://catalog.extension.oregonstate.edu/em8954.

Sullivan, D.M. and Andrews, N. Estimating plant available nitrogen release from cover crops, 2012. Pacific Northwest Extension Publication 636. Oregon State University, USA. https://catalog.extension.oregonstate.edu/pnw636.

Swistock, B., 2009. Estimating water use for the farm and home. Penn State University, College of Agricultural Sciences Cooperative Extension Service,. http://resources.cas.psu.edu/WaterResources/pdfs/water\%20use.pdf.

The National Trust, 2012. What's your beef? Swindon, UK.

The Organic Feed Company, 2011. Organic ewe and lamb feed. www.organicfeed.co.uk

Thomassen, M.A., K.J. van Calker, M.C.J. Smits, G.L. lepema, I.J.M. de Boer, 2008. Life cycle assessment of conventional and organic milk production in the Netherlands. Agricultural Systems, 96, 95-107.

Tidåker. P., C. Sundberg, I. Öborn, T. Kätterer, G. Bergkvist, 2014. Rotational grass/clover for biogas integrated with grain production - A life cycle perspective. Agricultural Systems 129, 133-141.

Tuomisto, H.L., I.D. Hodge, P. Riordan, D.W. Macdonald, 2012a. Does organic farming reduce environmental impacts? - A meta-analysis of European research. Journal of Environmental Management, 112, 309-320.

Tuomisto, H.L., Hodge, I.D., Riordan, P., Macdonald, P.W., 2012b. Comparing global warming potential, energy use and land use of organic, conventional and integrated winter wheat production. Ann. Appl. Biol. 161 (2), 116-126.

Van Zeijts, H., H. Leneman,A.W. Sleeswijk, 1999. Fitting fertilization in LCA: allocation to crops in a cropping plan. Journal of Cleaner Production, 7, 69-74.

Webb, N.,M. Broomfield, P. Brown, G. Buys, L. Cardenas, T. Murrells, Y. Pang, N. Passant, G. Thistlethwaite, J. Watterson, 2014. UK greenhouse gas inventory 1990 to 2012: Annual report for submission under the Framework Convention on Climate Change. Department of Energy and Climate Change (DECC), London.

Whiting, A. and A. Azapagic, 2014. Life cycle environmental impacts of generating electricity and heat from biogas produced by anaerobic digestion. Energy, 70, 181-193.

Wiedemann, S., S. Ledgard, B.K. Henry, M.-J. Yan, N. Mao, S. Russell, 2015. Application of life cycle assessment to sheep production systems: investigating co-production of wool and meat using case studies from major global producers, Int. J. Life Cycle Assess., 20, 463-476.

Williams, A.G., E. Audsley, D.L. Sandars, 2006. Determining the environmental burdens and resource use in the production of agricultural and horticultural commodities. Main Report. Defra Research Project IS0205. Bedford, Cranfield University and Defra. 
Life cycle greenhouse gas emissions from integrated organic farming: a systems approach
considering rotation cycles

Harish K. Jeswani, Namy Espinoza-Orias, Tim Crocker, and Adisa Azapagic

\section{Supplementary Information}

\section{List of tables}

Table S1 Land area and diesel consumption for different field operations

Table S2 Correction factors for diesel consumption in field operations over the rotation cycle

Table S3 Composition of ewes feed concentrate

Table S4 Sheep and lambs herd size over the rotation cycle

Table S5 Composition of pigs feed concentrate

Table S6 Pigs herd size over the rotation cycle

Table S7 Composition of feed concentrate for cows-in-milk

Table S8 Beef cattle herd size over the rotation cycle

Table S9 Dairy cattle herd size over the rotation cycle

Table S10 Global warming potential (GWP) of arable crops over the rotation cycle

Table S11. Land area used for different crops Table S12 Annual and total global warming potential (GWP) of animals and their products over the rotation cycle

Table S13 Mass allocation for the crop co-products

Table S14 Economic allocation for the crop co-products

Table S15 Fertiliser requirements of different crops

\section{List of figures}

Figure S1 Sheep and lambs herd size and lamb sales over the rotation cycle

Figure S2 Pigs herd size over the rotation cycle

Figure S1 Contribution of different activities to the global warming potential of crops 
Table S1 Land area and diesel consumption for different field operations

\begin{tabular}{|c|c|c|c|}
\hline Field operations & $\begin{array}{c}\text { Total area covered over } \\
\text { the } 7 \text {-year rotation } \\
\text { cycle [ha] }\end{array}$ & $\begin{array}{l}\text { Specific diesel } \\
\text { consumption } \\
{[\mathrm{l} / \mathrm{ha}]}\end{array}$ & Source \\
\hline Broadcasting & 118 & 2.3 & Williams et al. (2006) \\
\hline Combine harvesting & 1,788 & 21.7 & Williams et al. (2006) \\
\hline Drilling & 2,417 & 5.8 & Williams et al. (2006) \\
\hline Drying of grain & 1,630 & 56 & Downs and Hansen (1998) \\
\hline Fertiliser spreading & 3,191 & 12.9 & Williams et al. (2006) \\
\hline Harrow combing & 2,220 & 6.3 & Williams et al. (2006) \\
\hline Hoeing & 10 & 19.4 & Williams et al. (2006) \\
\hline Lime spreading & 138 & 6.5 & Williams et al. (2006) \\
\hline Planting & 45 & 4.7 & Frisby (2010) \\
\hline Ploughing & 1,822 & 19.8 & Farm data \\
\hline Power harrowing & 2,254 & 18.5 & Farm data \\
\hline Pressing & 1,821 & 4.2 & Farm data \\
\hline Rolling & 1,188 & 4.2 & Williams et al. (2006) \\
\hline Rotavating & 19 & 4.2 & Frisby (2010) \\
\hline Spraying manganese & 7 & 1.7 & Williams et al. (2006) \\
\hline Straw baling & 5,578 & 6.4 & Williams et al. (2006) \\
\hline Straw cutting/mowing & 3,920 & 34 & Williams et al. (2006) \\
\hline Terradisc & 2,345 & 4.2 & Frisby (2010) \\
\hline Undersowing & 72 & 4.9 & Bentley-Fox (2004) \\
\hline Whole crop harvesting & 21 & 10.9 & Dyer and Desjardin (2003) \\
\hline Bale handling (tonne) & 6048 & $1.3 \mathrm{l} /$ tonne & Dalgard et al. (2001) \\
\hline Internal product movement (tonne) & 24,870 & $0.3 \mathrm{l} /$ tonne & Ecoinvent $(2010)$ \\
\hline
\end{tabular}

Table S2 Correction factors for diesel consumption in field operations over the rotation cycle

\begin{tabular}{lrrrrrrr}
\hline $\begin{array}{l}\text { Diesel } \\
\text { consumption }\end{array}$ & Year 1 & Year 2 & Year 3 & Year 4 & Year 5 & Year 6 & Year 7 \\
\hline $\begin{array}{l}\text { Theoretical } \\
\text { consumption [l] }\end{array}$ & 45,941 & 46,993 & 52,583 & 52,842 & 57,467 & 58,118 & 58,180 \\
$\begin{array}{l}\text { Actual } \\
\text { consumption [l] }\end{array}$ & 40,103 & 41,618 & 40,460 & 40,865 & 51,702 & 53,229 & 56,435 \\
Correction factor & 0.87 & 0.89 & 0.77 & 0.77 & 0.90 & 0.92 & 0.97 \\
\hline
\end{tabular}

Table S3 Composition of feed concentrate for ewes

\begin{tabular}{lc}
\hline \multicolumn{1}{c}{ Ingredient } & $\begin{array}{c}\text { Concentration } \\
\text { a } \\
{[\%]}\end{array}$ \\
\hline Organic Barley & 50 \\
Organic maize & 20 \\
Organic sugar beet pulp & 12 \\
Organic soybean meal & 15 \\
Vitamins and minerals & 3 \\
\hline${ }^{\mathrm{a}}$ Estimated GHG for feed for ewes $=0.6 \mathrm{~kg} \mathrm{CO}_{2} \mathrm{e} . / \mathrm{kg}$
\end{tabular}

Table S4 Sheep and lambs herd size over the rotation cycle

\begin{tabular}{lcccccccc}
\hline Sheep & Average & Year 1 & Year 2 & Year 3 & Year 4 & Year 5 & Year 6 & Year 7 \\
& liveweight [kg] & & & & & & & \\
\hline Ewes (breeding sheep) & 60 & 483 & 401 & 361 & 303 & 382 & 429 & 430 \\
Rams (breeding sheep) & 80 & 17 & 13 & 17 & 16 & 11 & 12 & 15 \\
Lambs (<1 year) & 20 & 254 & 261 & 322 & 343 & 319 & 304 & 287 \\
Other sheep (> 1 year) & 50 & 24 & 21 & 33 & 3 & 23 & 5 & 0 \\
Ewes sold & 60 & 114 & 70 & 8 & 119 & 127 & 71 & 177 \\
Rams sold & 80 & 7 & 4 & 4 & 3 & 10 & 5 & 22 \\
Lambs sold & 20 & 654 & 566 & 719 & 413 & 462 & 378 & 404 \\
\hline
\end{tabular}


Table S5 Composition of pigs feed concentrate (Martins et al., 2002)

\begin{tabular}{|c|c|c|}
\hline Component & $\begin{array}{c}\text { Feed for } \\
\text { piglets }^{\mathrm{a}}[\%]\end{array}$ & $\begin{array}{l}\text { Feed for adult pigs } \\
{[\%]}\end{array}$ \\
\hline Organic wheat & 21.8 & 21.1 \\
\hline Organic barley & 15.8 & 19.3 \\
\hline Organic peas & 10.8 & 15.0 \\
\hline Organic rape expeller & 10.0 & 12.5 \\
\hline Organic oats & 11.9 & 11.6 \\
\hline Organic triticale & 10.0 & 5.0 \\
\hline Wheat feed & & 4.8 \\
\hline Organic soya expeller & 13.4 & 3.1 \\
\hline Organic molasses & & 3.0 \\
\hline Organic beans & 4.2 & 2.0 \\
\hline Vitamins and minerals & 1.0 & 1.4 \\
\hline $\mathrm{CaCO}_{3}$ (limestone) & 0.7 & 0.9 \\
\hline Organic soya oil & & 0.4 \\
\hline Dicalcium phosphate & 0.5 & \\
\hline Total & 100 & 100 \\
\hline
\end{tabular}

Table S6 Pigs herd size over the rotation cycle

\begin{tabular}{lcccccccc}
\hline Pigs & Average & Year 1 & Year 2 & Year 3 & Year 4 & Year 5 & \multirow{2}{*}{ Year 6 } & \multirow{2}{*}{ Year 7 } \\
& liveweight [kg] & & & & & & & \\
\hline Sows & 225 & 5 & 6 & 6 & 8 & 9 & 6 & 2 \\
Boars & 250 & 1 & 1 & 1 & 2 & 2 & 2 & 2 \\
Weaners & 18 & 18 & 22 & 15 & 15 & 28 & 26 & 12 \\
Growers & 30 & 18 & 22 & 15 & 15 & 50 & 26 & 12 \\
Sows sold & 225 & & & & 1 & 1 & 4 & 102 \\
Growers sold & 35 & 74 & 51 & 91 & 49 & 62 & 51 \\
\hline
\end{tabular}

Table S7 Composition of feed concentrate for cows-in-milk

\begin{tabular}{lc}
\hline \multicolumn{1}{c}{ Ingredient } & $\begin{array}{c}\text { Concentration }^{\mathrm{a}} \\
{[\%]}\end{array}$ \\
\hline Organic barley & 31 \\
Organic sunflower & 26 \\
Organic oats & 20 \\
Organic lucerne & 15 \\
Organic maize & 5 \\
Calcium carbonate & 1 \\
Sodium chloride & 1 \\
Magnesium dicalcium phosphate & 1 \\
\hline a Estimated GHG for feed for cows $=0.8 \mathrm{~kg} \mathrm{CO}_{2} \mathrm{e} / \mathrm{kg}$
\end{tabular}

Table S8 Beef cattle herd size over the rotation cycle

\begin{tabular}{lcccccccc}
\hline Beef cattle & $\begin{array}{c}\text { Average } \\
\text { liveweight [kg] }\end{array}$ & Year 1 & Year 2 & Year 3 & Year 4 & Year 5 & Year 6 & Year 7 \\
\hline Cows & 650 & 90 & 85 & 87 & 88 & 81 & 125 & 109 \\
Male < 1 year & 200 & 45 & 51 & 34 & 40 & 45 & 95 & 59 \\
Heifer < 1 year & 180 & 44 & 42 & 38 & 40 & 42 & 95 & 58 \\
Male 1 to 2 years & 400 & 58 & 64 & 76 & 67 & 72 & 60 & 84 \\
Heifer 1 to 2 years & 400 & 50 & 56 & 61 & 66 & 58 & 68 & 91 \\
Male > 2 years & 580 & 6 & 3 & 12 & 10 & 13 & 15 & 13 \\
Heifer > 2 years & 540 & 4 & 2 & 9 & 6 & 6 & 13 & 24 \\
Bulls & 1000 & 4 & 4 & 3 & 3 & 4 & 8 & 6 \\
Beef cattle sold & 550 & 131 & 112 & 130 & 137 & 159 & 206 & 191 \\
\hline
\end{tabular}


Table S9 Dairy cattle herd size over the rotation cycle

\begin{tabular}{|c|c|c|c|c|c|c|c|}
\hline \multirow[b]{2}{*}{ Dairy cattle } & \multicolumn{7}{|c|}{ Number of heads } \\
\hline & Year 1 & Year 2 & Year 3 & Year 4 & Year 5 & Year 6 & Year 7 \\
\hline Cows-in-milk & 115 & 131 & 142 & 138 & 146 & 134 & 125 \\
\hline Dry cows & 35 & 34 & 40 & 42 & 42 & 42 & 44 \\
\hline Barren cows & 2 & 3 & 1 & 1 & 1 & 0 & 0 \\
\hline Young stock < 1 year & 32 & 39 & 33 & 34 & 35 & 32 & 31 \\
\hline Young stock 1 to 2 years & 31 & 34 & 37 & 35 & 37 & 34 & 26 \\
\hline Young stock $>2$ years & 15 & 16 & 20 & 22 & 20 & 24 & 27 \\
\hline $\begin{array}{l}\text { Young stock male to beef } \\
\text { (<1 year) } \\
\text { Young stock female to beef }\end{array}$ & 30 & 40 & 30 & 45 & 44 & 36 & 57 \\
\hline (<1 year) & 20 & 29 & 24 & 36 & 43 & 44 & 39 \\
\hline Dairy cattle sold & 18 & 26 & 32 & 32 & 41 & 28 & 47 \\
\hline
\end{tabular}

Table S10 Annual and total global warming potential (GWP) of arable crops over the rotation cycle

\begin{tabular}{|c|c|c|c|c|c|c|c|c|}
\hline \multirow[b]{2}{*}{ Crop } & \multicolumn{7}{|c|}{ Annual GWP [t $\mathrm{CO}_{2}$-eq./yr] } & \multirow{2}{*}{$\begin{array}{c}\text { Full rotation } \\
\text { cycle }\left[\mathrm{CO}_{2} \text {-eq.] }\right.\end{array}$} \\
\hline & Year 1 & Year 2 & Year 3 & Year 4 & Year 5 & Year 6 & Year 7 & \\
\hline Winter wheat grains & 47.4 & 68.9 & 91.0 & 66.9 & 61.3 & 63.8 & 39.2 & 438.6 \\
\hline Spring oat grains & 86.7 & 73.3 & 174.2 & 95.1 & 133.2 & 127.0 & 91.1 & 780.7 \\
\hline Spring barley grains & 28.3 & 48.4 & 25.8 & 29.3 & 44.5 & 43.2 & 54.8 & 274.4 \\
\hline Spring beans & 14.0 & 28.2 & 10.5 & 18.4 & 45.4 & 26.6 & 6.5 & 149.5 \\
\hline Rye & 16.9 & 22.2 & 5.5 & 9.7 & 9.7 & 9.6 & 14.4 & 88.0 \\
\hline Straw (all crops) & 74.4 & 71.0 & 116.5 & 83.0 & 120.6 & 97.2 & 81.5 & 644.1 \\
\hline Silage & 185.7 & 177.3 & 239.5 & 194.5 & 283.2 & 289.7 & 296.2 & $1,666.1$ \\
\hline
\end{tabular}

Table S11 Land area used for different crops

\begin{tabular}{lccccccc}
\hline Crops & Year $\mathbf{1}$ & Year $\mathbf{2}$ & Year $\mathbf{3}$ & $\begin{array}{c}\text { Area (ha) } \\
\text { Year 4 }\end{array}$ & Year 5 & Year 6 & Year 7 \\
\hline Wheat & 82 & 86 & 106 & 100 & 77 & 75 & 41 \\
Oats & 86 & 72 & 101 & 91 & 89 & 79 & 79 \\
Barley & 31 & 47 & 37 & 36 & 49 & 47 & 60 \\
Beans & 10 & 26 & 9 & 16 & 44 & 24 & 6 \\
Rye & 30 & 32 & 14 & 16 & 19 & 20 & 27 \\
\hline
\end{tabular}

Table S12 Annual and total global warming potential (GWP) of animals and their products over the rotation cycle

\begin{tabular}{lrrrrrrrr}
\hline & & \multicolumn{4}{c}{ Annual GWP [t CO $\mathbf{C O}_{2}$-eq./yr] } & \multicolumn{2}{c}{ Full rotation } \\
& Year 1 & Year 2 & Year 3 & Year 4 & Year 5 & Year 6 & Year 7 & cycle [t CO $_{2}$-eq.] \\
\hline Sheep and lamb & 115.2 & 103.4 & 103.7 & 93.8 & 107.8 & 97.0 & 109.3 & 730.2 \\
Wool & 31.7 & 30.5 & 28.8 & 21.2 & 27.2 & 39.7 & 26.8 & 205.9 \\
Pigs & 10.4 & 10.7 & 14.0 & 11.4 & 16.0 & 16.6 & 9.9 & 88.8 \\
Beef cattle & 675.9 & 636.7 & 725.3 & 759.4 & 865.4 & 1041.6 & 1056.4 & 5760.8 \\
Dairy cows & 46.3 & 50.5 & 53.9 & 55.1 & 54.9 & 54.5 & 35.4 & 350.6 \\
Milk & 786.5 & 788.1 & 925.7 & 917.2 & 906.3 & 909.7 & 913.9 & 6147.3 \\
\hline
\end{tabular}

Table S13 Mass allocation for the factors for products and co-products [\%]

\begin{tabular}{llrrrrrrr}
\hline Sub-system & $\begin{array}{l}\text { Products and } \\
\text { co-product }\end{array}$ & Year 1 & Year 2 & Year 3 & Year 4 & Year 5 & Year 6 & Year 7 \\
& Wheat grains & 46 & 47 & 48 & 46 & 42 & 46 & 46 \\
Wheat & Wheat straw & 54 & 53 & 52 & 54 & 58 & 54 & 54 \\
Oat & Oat grains & 61 & 70 & 60 & 61 & 56 & 61 & 61 \\
& Oat straw & 39 & 30 & 40 & 39 & 44 & 39 & 39 \\
Barley & Barley grains & 51 & 66 & 49 & 51 & 43 & 51 & 51 \\
& Barley straw & 49 & 34 & 51 & 49 & 57 & 49 & 49 \\
Rye & Rye grains & 41 & 49 & 34 & 41 & 44 & 41 & 41 \\
& Rye straw & 59 & 51 & 66 & 59 & 56 & 59 & 59 \\
Dairy & Milk & 98.6 & 98.3 & 97.9 & 98.0 & 97.1 & 98.0 & 96.8 \\
& Meat \& stock & 1.4 & 1.7 & 2.1 & 2.0 & 2.9 & 2.0 & 3.2 \\
Sheep & Lamb \& sheep & 93 & 93 & 93 & 95 & 94 & 90 & 94 \\
& Wool & 7 & 7 & 7 & 5 & 6 & 10 & 6 \\
\hline
\end{tabular}


Table S14 Economic allocation factors for products and co-products ${ }^{\mathrm{a}}[\%]$

\begin{tabular}{llrrrrrrr}
\hline Sub-system & $\begin{array}{l}\text { Products and } \\
\text { co-product }\end{array}$ & Year 1 & Year 2 & Year 3 & Year 4 & Year 5 & Year 6 & Year 7 \\
& Wheat grains & 74 & 75 & 76 & 74 & 71 & 74 & 74 \\
& Wheat straw & 26 & 25 & 24 & 26 & 29 & 26 & 26 \\
Oat & Oat grains & 82 & 87 & 81 & 82 & 79 & 82 & 82 \\
& Oat straw & 18 & 13 & 19 & 18 & 21 & 18 & 18 \\
Barley & Barley grains & 77 & 86 & 76 & 77 & 71 & 77 & 77 \\
& Barley straw & 23 & 14 & 24 & 23 & 29 & 23 & 23 \\
Rye & Rye grains & 67 & 74 & 60 & 67 & 70 & 67 & 67 \\
\multirow{2}{*}{ Dairy } & Rye straw & 33 & 26 & 40 & 33 & 30 & 33 & 33 \\
& Milk & 95.8 & 92.4 & 95.6 & 96.1 & 95.7 & 93.6 & 91.3 \\
Sheep & Meat \& stock & 4.2 & 7.6 & 4.4 & 3.9 & 4.3 & 6.4 & 8.7 \\
& Lamb \& sheep & 98.4 & 98.2 & 99.4 & 97.0 & 98.7 & 98.8 & 99.1 \\
& Wool & 1.6 & 1.8 & 0.6 & 3.0 & 1.3 & 1.2 & 0.9 \\
\hline
\end{tabular}

${ }^{a}$ Prices for the cereals and straw are from Lampkin et al. (2008). The economic factors for the dairy and sheep units are based on the farm revenue data.

Table S15 Fertiliser requirements of different crops (DEFRA, 2010)

\begin{tabular}{lc}
\hline Crop & N requirements $\mathbf{( k g / h a )}$ \\
\hline Wheat & 220 \\
Oat & 120 \\
Barley & 140 \\
Rye & 120 \\
Beans & 0 \\
Grass & 200 \\
\hline
\end{tabular}

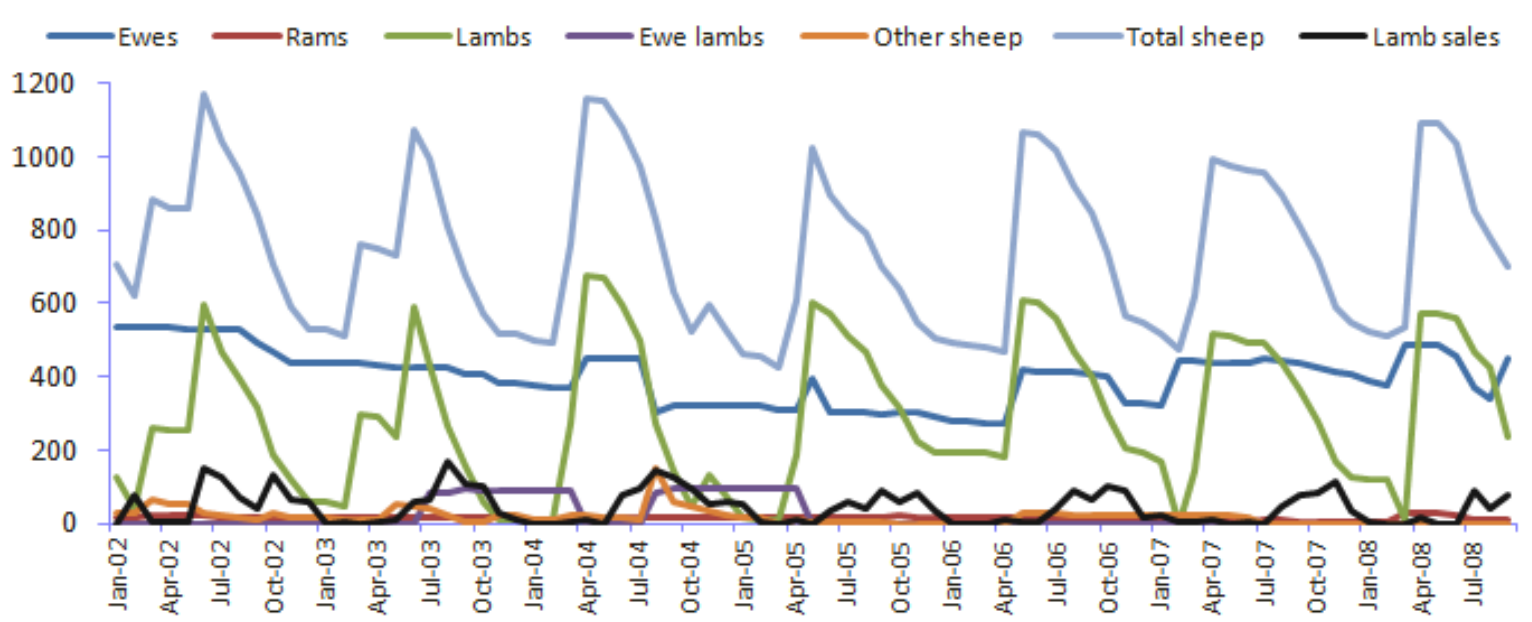

Figure S1 Sheep and lambs herd size and lamb sales over the rotation cycle [no. of heads]

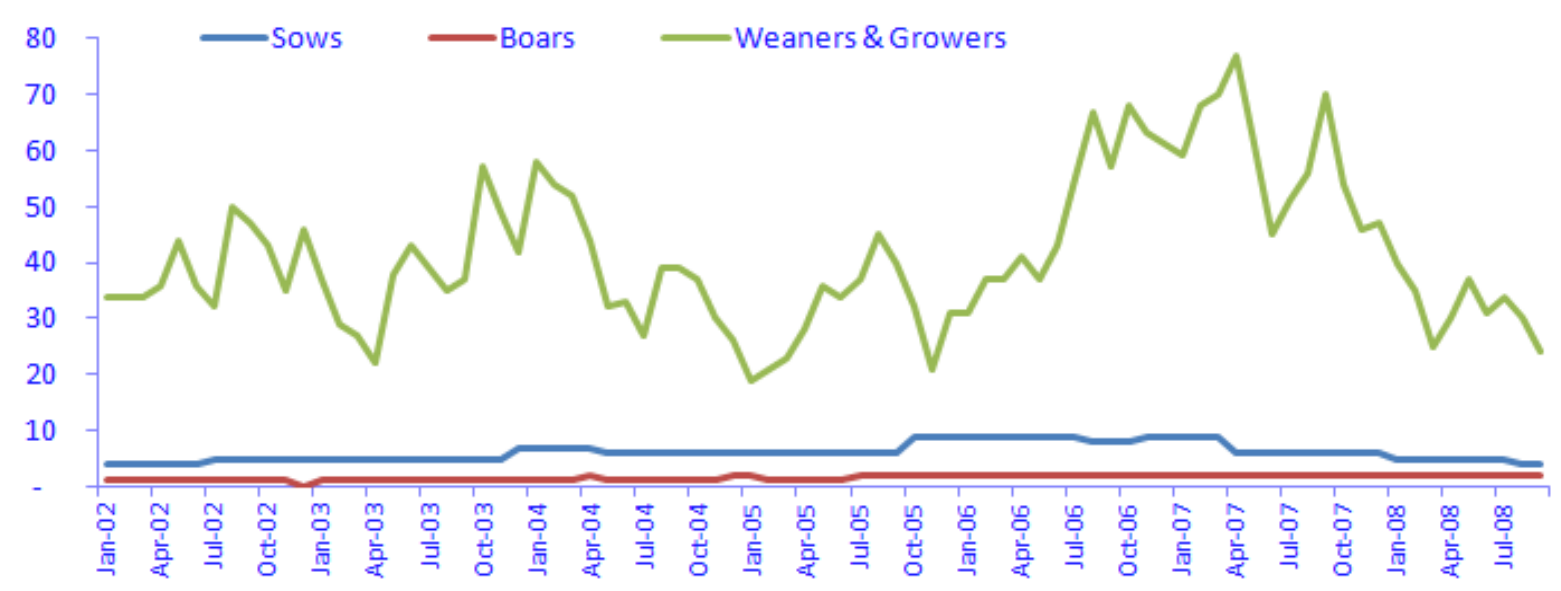

Figure S2 Pigs herd size over the rotation cycle [no. of heads] 


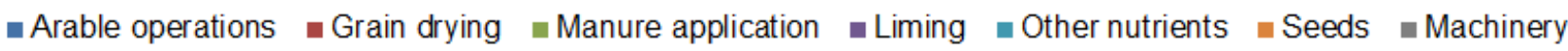

\section{Winter wheat}

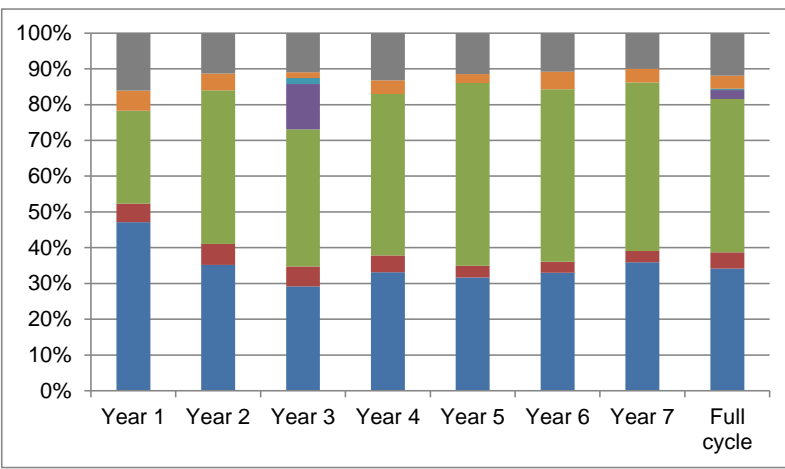

\section{Barley}

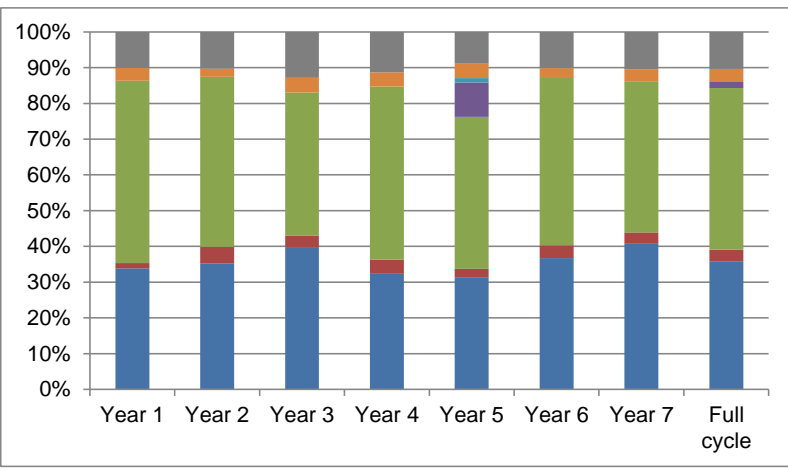

\section{Rye}

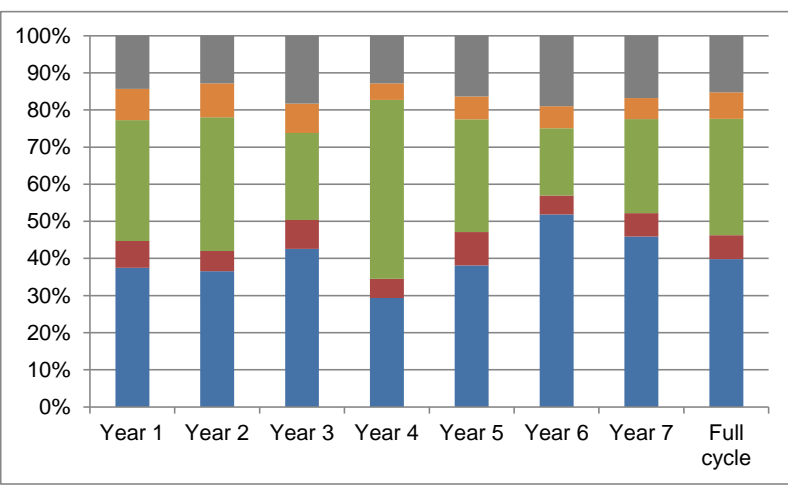

\section{Spring oats}

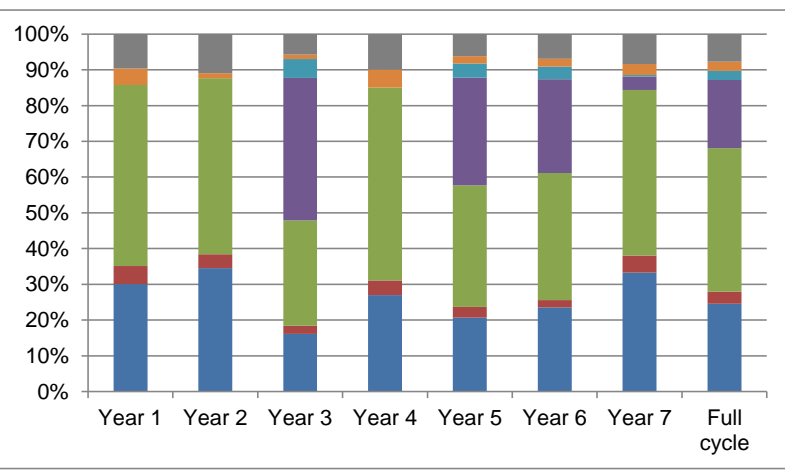

\section{Beans}

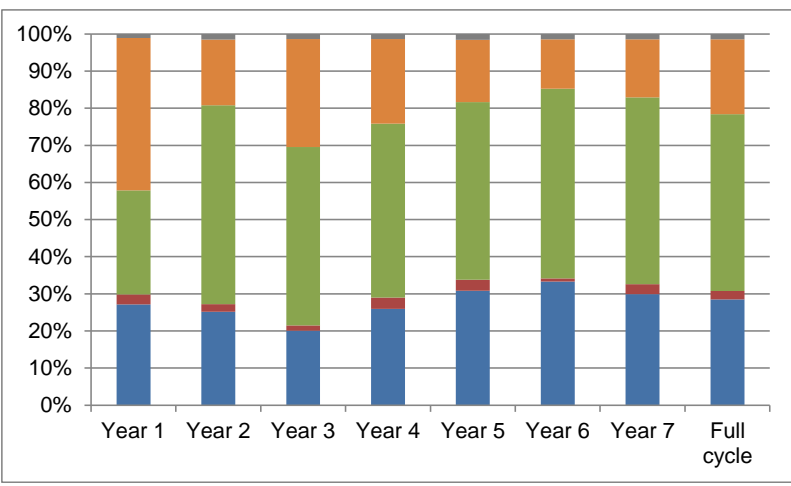

\section{Silage}

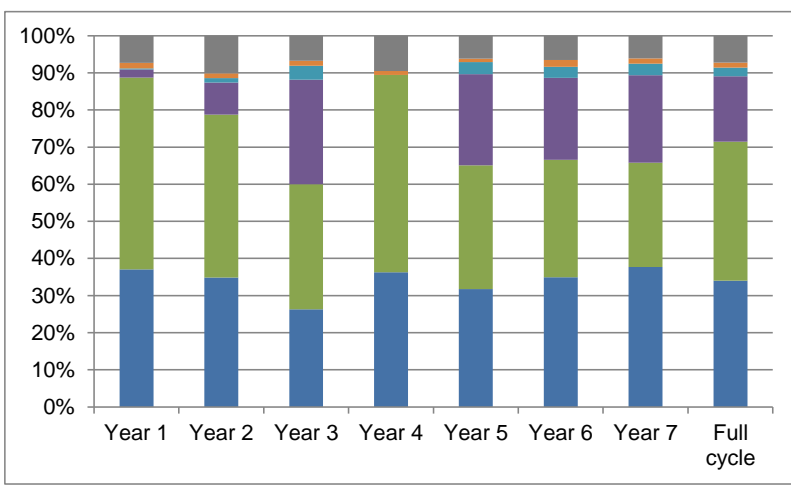

\section{Whole farm (all crops)}

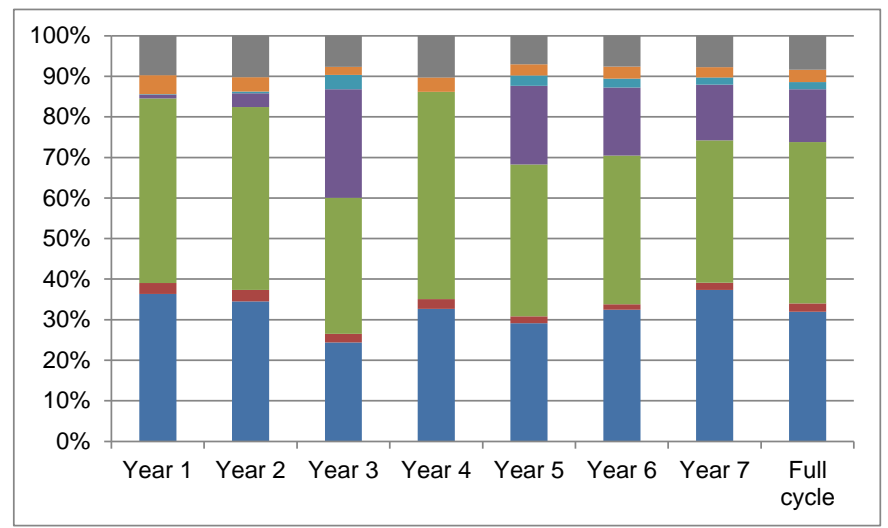

Figure S3 Contribution of different farming operations to global warming potential of crops

[Grain drying: drying using heated air. Seeds: cultivation and transport of seeds; Other nutrients: manufacture and transport of lime and trace minerals. Lime application $\left(\mathrm{CO}_{2}\right.$ emissions): emissions from the application of lime to the soil; Manure application ( $\mathrm{N}_{2} \mathrm{O}$ emissions): direct and indirect $\mathrm{N}_{2} \mathrm{O}$ emissions from the application of manure. Arable operations: use of machinery and drying of seeds after harvest.]. 


\section{References}

Bentley-Fox, H., 2004. Energy inputs into the average arable/forage crop at Sheepdrove organic farm 2003/4. Elm Farm Research Centre, UK. http://orgprints.org/10322/1/report arable(energy) -.pdf.

Dalgaard, T., N. Halberg, J.R. Porter, 2001. A model for fossil energy use in Danish agriculture used to compare organic and conventional farming. Agriculture, Ecosystems and Environment, 87, 51-65.

Department for Agriculture, Food and Rural Affairs (DEFRA), 2010. Fertiliser manual (RB 209). $8^{\text {th }}$ edition, London.

Downs, H.W., R.W. Hansen, 1998. Estimating farm fuel requirements.Bulletin No. 5.006. Colorado State University Cooperative Extension. Available at www.colostate.edu/Depts/CoopExt.

Dyer, J.A., R.L. Desjardins, 2003. The impact of farm machinery management on the greenhouse gas emissions from Canadian agriculture. Journal of Sustainable Agriculture, 22, 59-74.

Ecoinvent Centre, 2010. Swiss Centre for Life Cycle Inventories. Ecoinvent Database v 2.2. Dübendorf.

Frisby, J., 2010. Fuel requirement estimates for selected field operations. Department of Agricultural Engineering, University of Missouri - Columbia.. Last accessed July 2014http://www.todaystractors.com/articles/art1.html.

Lampkin, N., M. Measures, S. Padel, 2008. 2009 Organic farm management handbook. Organic Research Group, Institute of Biological, Environmental and Rural Sciences, Aberystwyth University, Wales.

Martins, A.; Kelly, H.; Day, J.; Stopes, C.; Browning, H.; Edwards, S. Optimising organic pig production. A guide to good practice. DEFRA, 2002.

Williams, A.G., E. Audsley, D.L. Sandars, 2006. Determining the environmental burdens and resource use in the production of agricultural and horticultural commodities. Main Report. Defra Research Project IS0205. Bedford, Cranfield University and Defra. 